\title{
A State of the Art Review of Dispersion and Inspection Techniques for Carbon Nanotubes (CNTs) into Matrix Composites
}

\author{
Hussein Zein ${ }^{1,2, *}$ and Yaser A. Al-Shataif ${ }^{1}$ \\ ${ }^{1}$ Mechanical Engineering Department, College of Engineering, Qassim University, Buraidah 51452, Saudi Arabia \\ ${ }^{2}$ Mechanical Design and Production Department, Faculty of Engineering, Cairo University, Giza 12613, Egypt
}

\begin{abstract}
This review is provided with a detailed overview of common reinforcement and inspection techniques for producing reinforced composite materials. This study focuses on the state of the art for how used carbon nanotubes (CNTs) as a reinforced material to obtain micro-composite and nano-composite materials. On the other hand, up to now, the major problem is to get a uniform dispersion of the CNTs in the wanted reinforced composite material. So, this review paper emphasizes on several techniques which are utilized for improving the dispersion of CNTs in a metallic powder, such as copper $(\mathrm{Cu})$, aluminum $(\mathrm{Al})$, and magnesium $(\mathrm{Mg})$ as matrix composites. Furthermore, this review presents two different experimental techniques (destructive testing and non-destructive testing) with the purpose of detection of CNTs dispersion in the reinforced composite material. As a result, this review is a helpful tool for all scientists for deciding which technique is more suitable for their research composite materials. [doi:10.2320/matertrans.MT-M2019221]
\end{abstract}

(Received August 7, 2019; Accepted October 15, 2019; Published December 25, 2019)

Keywords: carbon nanotubes, dispersion, reinforcement techniques, destructive testing, non-destructive testing

\section{Introduction}

A large number of research efforts were placed into the development of nanotube-based polymer composites ${ }^{1-6)}$ with some efforts into the development of ceramic ${ }^{7-9)}$ and metal ${ }^{10-24)}$ composites with CNT reinforcements. Interest into the development of metal CNTs reinforced composites has, however, grown considerably and in particular the carbon nanotube/matrix composites. A number of studies have reported that the use of CNTs reinforcements enhanced the mechanical properties of metal matrices composites. ${ }^{25-30)}$ The importance of composite materials reinforced by CNTs and graphene nano-plates (GNPs) comes from using it in many applications due to its high strength properties and lightweight.

\subsection{Copper applications}

Copper and its alloys are extensively utilized in many industries due to its physical and mechanical properties. They are used in many applications, for example, electrical, marine, automotive, aircraft, and aerospace applications. Also, due to new advancements in electronics technology, the need for a material with higher strength and higher electrical conductivity is increased. The copper alloys are the commonly used materials for these purposes. ${ }^{31-35)}$

\subsection{Aluminum applications}

Aluminum alloys and aluminum matrix composites have used in numerous applications in many industries such as automotive, aircraft, aerospace, military, electricity, and marine parts, such as engine, cylinder blocks, pistons, and piston insert rings. ${ }^{36-38)}$ Aluminum alloys and their composites have advantageous properties for industrial applications, such as high specific strength, ${ }^{39)}$ good corrosion resistance, ${ }^{40)}$ high thermal conductivity, ${ }^{41)}$ low coefficient of thermal expansion, ${ }^{38)}$ low electrical resistivity, ${ }^{42}$ and high damping capacity. ${ }^{43}$ ) So, aluminum alloys are the most

*Corresponding author, E-mail: dr.husseinzein@qec.edu.sa important material in the aircraft construction industry, such as, in the aircraft body and airfoil wings. ${ }^{44,45)}$ Also, Aluminium composite materials (ACMs) have excellent properties for wear resistance, temperature creeps resistance and fatigue strength. ${ }^{38)}$ ACMs are substituted with cast iron and bronze alloys where the tribology properties are very high for wear and seizure resistance. ${ }^{46,47)}$ Applications of aluminum alloys in the automobile and aircraft industries have been created with regard to decreasing fuel consumption and insulating the environment, where they can effectively substitute steel and cast iron components, ${ }^{48}$ ) for example in, cylinder blocks, brake drums, cylinder liners and drive shafts, with the aim of decrease fuel and pollution. ${ }^{36)}$ Aluminum alloys have low mechanical properties and tribological properties. This can be overcome by inserting ceramic particles, such as $\mathrm{Al}_{2} \mathrm{O}_{3},{ }^{49)}$ silicon carbide $\left.(\mathrm{SiC}),{ }^{50)} \mathrm{BN},{ }^{51}\right)$ and carbon nanotubes (CNTs) materials depending on their applications.

\subsection{Magnesium applications}

Magnesium has great attention due to its material density $\left(1.74 \mathrm{~g} / \mathrm{cm}^{3}\right)$ which is lighter in weight than aluminum density (about \%35). ${ }^{52,53)}$ Also, it has a high strength to weight ratio and specific modulus with good machinability. ${ }^{54)}$ Magnesium comes in an eighth of its abundance on the earth $^{55)}$ and has the lightest structural metal material with high chemical activity and energy density. ${ }^{56)}$ All of those features, encourage aircraft industry, automotive ${ }^{56)}$ and field of battery ${ }^{57,58)}$ to use it widely. On the other hand, the magnesium has low corrosion, wear resistance and inferior ductility due to its hexagonal closed packing (HCP) structure. ${ }^{59,60)}$ Researchers have investigated those problems by improving magnesium composites with reinforcements of particulate. ${ }^{61-63)} \mathrm{Al}_{2} \mathrm{O}_{3}, \mathrm{SiC}$, and $\mathrm{B} 4 \mathrm{C}$ are commonly used in the scale of micro-size particulate reinforcements but those reinforcements improve the modulus and hardness while they stabilize ductility. ${ }^{64)}$ In the main time, Nano-size reinforcement such as CNTs and nanoparticles have proven enhancement in mechanical properties. ${ }^{65)}$ 
Magnesium is the third most commonly used structural metal following iron and aluminum. ${ }^{66)}$ Magnesium is used in super-strong, lightweight materials and alloys. For instance, when implanted with silicon carbide nanoparticles, it has an extremely high specific strength. ${ }^{67)}$ In the past, magnesium was one of the major aerospace structure metals and was utilized for German military aircraft since World War I and widely used for German aircraft in World War II. The Germans gave the name "Elektron" for magnesium alloy, a term which is still utilized today. In the marketable aerospace industry, magnesium was generally limited to engine-related elements, because of fire and corrosion problems. Now, magnesium alloy is utilized in aerospace is increasing, driven by the importance of fuel economy. ${ }^{68)}$ Improvement and assessment of new magnesium alloys carry on notably Elektron 21, which (in the evaluation) has been proven appropriate for the aerospace engine, internal, and airframe components. ${ }^{69)}$

From the 1950s to the current time, magnesium alloys and magnesium matrix composites have utilized in many applications in many industries such as an automobile, aircraft, aerospace, military, and electrical components. For the automobile industry, due to high corrosion resistance and high strength in the new magnesium alloys, these alloys are extensively utilized for manufacturing wheels, seat frames, steering wheels, crankcase, and transmission housing. As a result of light weight and high strength properties for magnesium composites, it is used for fabricated aircraft, and aerospace components, such as cast helicopter transmission housings, landing wheels, gearbox housings, and helicopter rotor fittings. Due to low weight and excellent mechanical and electrical properties, magnesium is extensively utilized for the production of mobile phones, laptop, tablet, and camera casings. This trend is a result of enhancement in corrosion resistance of magnesium alloys and development of new alloys withstanding creep, fatigue and elevated temperatures. For environmental protection, magnesium alloys and their composites have many features, such as more fuel-efficient transportation, better recycling capabilities, and better emission protection. ${ }^{70-83)}$

\section{Carbon Nanotubes (CNTs)}

In 1991, the carbon nanotubes (CNTs) have been discovered by Iijima. ${ }^{84)}$ Because of its extraordinary mechanical properties such as tensile strength and elastic modulus around a $(150 \mathrm{GPa})$ and $(1 \mathrm{Tpa})$ respectively. Since then, a considerable amount of research has been carried out on CNTs which has shown them to have very peculiar electronic and thermal properties such as electric current capacity that exceed that of copper wires by 1000 times, ${ }^{18)}$ a thermal conductivity greater than that of diamond, ${ }^{85)}$ etc. On account of those remarkable characteristics, the CNTs become superior nano-filler (reinforcement) of composites to improve its properties. ${ }^{86)}$ According to their shape, the carbon nanotubes (CNTs) were classified into two main categories: (1) single-walled carbon nanotube (SWNT) which contain a one-atom-thick sheet of carbon (graphene) rolled to the tube, and (2) multi-walled carbon nanotubes which contain many graphene layers. ${ }^{87)}$ There are some studies on the influence of geometrical parameters of carbon nanotubes for both types (single-walled and multiwalled) on its mechanical and electrical properties. ${ }^{88,89)}$ Also, Mohsen et al. studied the influence of geometrical parameters of multiwalled carbon nanotubes on the mechanical strength and the dispersion of CNTs of cement composites. ${ }^{90)}$ Some studies have shown a reinforcement of CNTs into composite materials which have to increase the mechanical properties. ${ }^{91,92)}$ Sónia Simões et al. (2017) reinforced MWCNTs into Aluminium due to their results; there was a significant increase in mechanical properties. ${ }^{92)}$ Z.Y. Liu et al. (2017) used $\mathrm{Al}-5 \mathrm{Mg}$ composites as a matrix and the results were positive. ${ }^{93)}$ On the other hand, G.Q. Han et al. (2016) demonstrated in his research the CNTs reinforced magnesium alloys decrease the strength and yield but improve the ductility of magnesium. ${ }^{94)}$

\section{Reinforcement or Dispersion Techniques}

A metallic powder as matrix composites can be acquired by dispersing reinforcement particles in metallic powder utilizing solid or liquid phase techniques. Carbon nanotubes (CNTs) are favorable reinforcements for lightweight and high strength composites due to their exceptional properties. However, until now, the major difficulty is to get a uniform dispersion of the CNTs in the required material matrix. Relatively a few techniques have been researched to assist to improve the dispersion of CNTs in a polymer matrix. But not much research has been performed on how to disperse CNTs in metal matrices. ${ }^{95}$ )

The Effectiveness of CNTs on the matrix composites has attracted many researchers. CNTs have turn out to be well-known in the modern materials due to its reinforced enhancement of the mechanical, the thermal, and the electrical properties of $\mathrm{Cu}$ and $\mathrm{Al},{ }^{94,96)}$ pure the $\mathrm{Mg},{ }^{97)} \mathrm{Mg}-$ $6 \mathrm{Al}$ alloy, ${ }^{98)}$ and AZ31/AZ81 alloys. ${ }^{99,100)}$ Figure 1 shows a flowchart of reinforcement CNTs into the metallic matrix in the shape of powders.

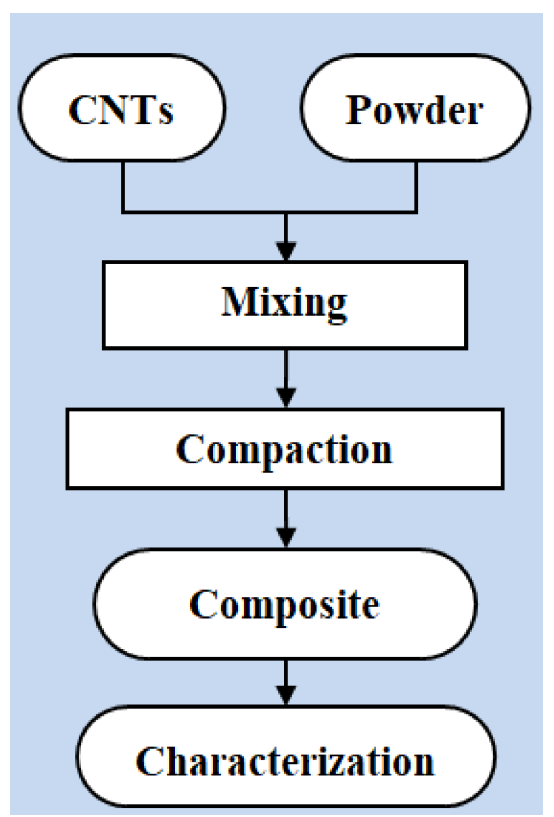

Fig. 1 Flow chart of reinforcement CNTs into Metallic Powders. 
Table 1 Techniques of CNTs reinforcements into metallic powders. ${ }^{95,102-115)}$

\begin{tabular}{|c|c|c|c|c|c|}
\hline \multicolumn{2}{|c|}{ Technique Name } & \multirow[b]{2}{*}{$\begin{array}{l}\text { Technique's Description } \\
\text { The centrifugal forces are } \\
\text { created by a planetary disk } \\
\text { with grinding jars, connected } \\
\text { to it, are applied to the mixture } \\
\text { and milling balls in the bowl. }\end{array}$} & \multirow[b]{2}{*}{$\begin{array}{l}\text { Advantages } \\
\text { - Suitable for research } \\
\text { purposes. } \\
\text { - Suitable for Solid, dry } \\
\text { and wet mixture. }\end{array}$} & \multirow[b]{2}{*}{$\begin{array}{l}\text { Disadvantages } \\
\text { - Breaking the CNTs } \\
\text { - A very small amount of } \\
\text { powder. } \\
\text { - A relatively long time of } \\
\text { milling. } \\
\text { - Poor mixing [116]. }\end{array}$} & \multirow{2}{*}{$\begin{array}{l}\text { Figures } \\
\text { Figure } 2\end{array}$} \\
\hline \multirow{3}{*}{ 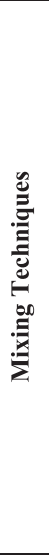 } & $\begin{array}{l}\text { Low } \\
\text { Energy Ball } \\
\text { Milling }\end{array}$ & & & & \\
\hline & $\begin{array}{l}\text { Arc } \\
\text { Melting } \\
\text { Technique }\end{array}$ & $\begin{array}{l}\text { Re-melting the Powders and } \\
\text { CNTs together many times by } \\
\text { electrodes to ensure the } \\
\text { homogeneity of the mixture. }\end{array}$ & $\begin{array}{l}\text { - No need for a } \\
\text { secondary process. } \\
\text { - Low porosity. } \\
\text { - Low energy } \\
\text { consumption. } \\
\text { - Faster operation } \\
\end{array}$ & - Big crystal grains & Figure 3 \\
\hline & $\begin{array}{l}\text { Mechanical } \\
\text { stirring }\end{array}$ & $\begin{array}{l}\text { It is a technique of composite } \\
\text { materials manufacture, in } \\
\text { which a dispersed phase CNTs } \\
\text { is mixed with a molten matrix } \\
\text { (powders) by means of } \\
\text { mechanical stirring. }\end{array}$ & $\begin{array}{l}\text { - Better results in the } \\
\text { Semi-solid condition } \\
\text { of the dispersed } \\
\text { phase. } \\
\text { - Simple and low cost. }\end{array}$ & $\begin{array}{l}\text { - The dispersed phase is } \\
\text { limited. } \\
\text { - Mixtures not always } \\
\text { perfectly homogenous. }\end{array}$ & Figure 4 \\
\hline \multirow{4}{*}{ 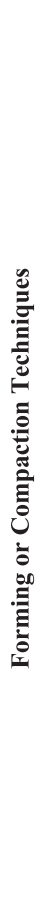 } & $\begin{array}{l}\text { Hot } \\
\text { Pressing }\end{array}$ & $\begin{array}{l}\text { It is a forming process where } \\
\text { the CNTs and the powders are } \\
\text { compacted under high } \\
\text { pressure (axial or isostatic) at } \\
\text { elevated temperature in which } \\
\text { the CNTs and the powders are } \\
\text { sintered into a single bulk } \\
\text { sample. }\end{array}$ & $\begin{array}{l}\text { - High density(low } \\
\text { porosity) } \\
\text { - Less sensitive to } \\
\text { powder's size shape } \\
\text { and distribution. } \\
\text { - Strong bonding. }\end{array}$ & $\begin{array}{l}\text { - Take a lot of time to heat } \\
\text { the mold. } \\
\text { - Expensive technique } \\
\text { because of the heating and } \\
\text { pressure system. } \\
\text { - Powders Oxidation } \\
\text { - Bonding powder particle } \\
\text { inside the cavity. }\end{array}$ & Figure 5 \\
\hline & $\begin{array}{l}\text { Cold } \\
\text { Pressing }+ \\
\text { Sintering. }\end{array}$ & $\begin{array}{l}\text { It is a materials process } \\
\text { technique in which high } \\
\text { pressure is applied, converting } \\
\text { loose powders to single } \\
\text { compact call green compacts } \\
\text { then processed to the sintering } \\
\text { process. }\end{array}$ & $\begin{array}{l}\text { - Highest safety. } \\
\text { - Long life of the die. } \\
\text { - Reduce mechanical } \\
\text { stress. } \\
\text { - Massive production. } \\
\text { - Closed tolerance. }\end{array}$ & $\begin{array}{l}\text { - Effect by powder's size } \\
\text { shape and distribution. } \\
\text { - Limit on the complexity of } \\
\text { shapes } \\
\text { - The produced sample } \\
\text { called Green Compact, } \\
\text { Need a secondary } \\
\text { operation like sintering. }\end{array}$ & Figure 6 \\
\hline & $\begin{array}{l}\text { Spark } \\
\text { Plasma } \\
\text { Sintering. }\end{array}$ & $\begin{array}{l}\text { A DC current directly passes } \\
\text { through the powders via } \\
\text { graphite rams which is } \\
\text { simultaneous pressing. The } \\
\text { DC generates Heat which } \\
\text { causes the bonding between } \\
\text { the particles. }\end{array}$ & $\begin{array}{l}\text { - Uniform and fast } \\
\text { sintering process. } \\
\text { - Low grain growth } \\
\text { - Sintering and } \\
\text { compaction in one } \\
\text { operation. }\end{array}$ & $\begin{array}{l}\text { - Only simple symmetrical } \\
\text { shapes can be prepared. } \\
\text { - Expensive technique. }\end{array}$ & Figure 7 \\
\hline & Infiltration & $\begin{array}{l}\text { Dispersed of CNTs by soaking } \\
\text { it in a molten matrix metal } \\
\text { (powders), which fills the } \\
\text { space between CNTs }\end{array}$ & $\begin{array}{l}\text { - Very low residual } \\
\text { porosity } \\
\text { - Complex shapes can } \\
\text { be fabricated. } \\
\text { - Low cost. } \\
\text { - Short production time. }\end{array}$ & $\begin{array}{l}\text { - The high temperature of } \\
\text { molten powders may cause } \\
\text { damage to the fibers. } \\
\text { - Lower mechanical } \\
\text { properties of the resulting } \\
\text { composite }\end{array}$ & Figure 8 \\
\hline
\end{tabular}

In the last few years, the researchers have been facing two major difficulties in reinforced CNTs into the material: (1) homogenous dispersion of CNTs, and (2) the perfect interfacial bond between CNTs and the material matrix which mainly affect the load transfer which produces high strength material. ${ }^{101)}$ Techniques of CNTs reinforcements into metallic powders are divided into two categories: (1) Mixing Techniques, and (2) Forming or Compaction Techniques. Table 1 presents all the details of these Techniques. While Table 2 displays the comparisons between the results, type of reinforcement and matrix, the used technique, and the description techniques of CNTs.

\section{Research Work on Experimental Methods for the Inspection Process}

The current work presents two different experimental methods (destructive and non-destructive) with the purpose of emphasis more researches in this specific field of investigation.

\subsection{Destructive testing}

In 2003, the primary goal of Thostenson and Chou ${ }^{144)}$ was to enhance understanding of the structure/size influence of the CNTs on the stability of composites strengthened with nanotube. They came to the conclusion that composite stability is depending on the CNT dimensions.

In 2007, Bakshi et al. ${ }^{145)}$ designed MWCNTs reinforced UHMWPE composite films by electrostatic spraying accompanied by consolidation. Their experimental test demonstrated a decrease in stress to failure from 14.3 to 12.4 MPa, $82 \%$ increase in Young's modulus, and strain to failure from $3.9 \%$ to $1.4 \%$ due to $5 \%$ adding of MWCNT. In 2010, Kulkarni et al. ${ }^{146)}$ discovered numerically and experimentally the elastic behavior of a CNT composite reinforced. A multi scale modeling method and the finite element modeling were used for discovering the characteristics of the CNT composite reinforced. By using a multi scale simulation, Savvas et al. ${ }^{147)}$ discovered the effect of interfacial shear stability on the damping and mechanical characteristics of CNT composite reinforced. Their mathematical results 


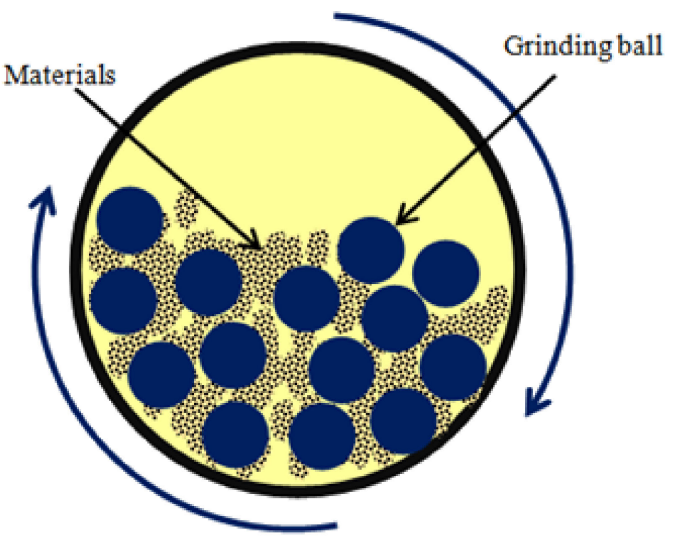

(a)

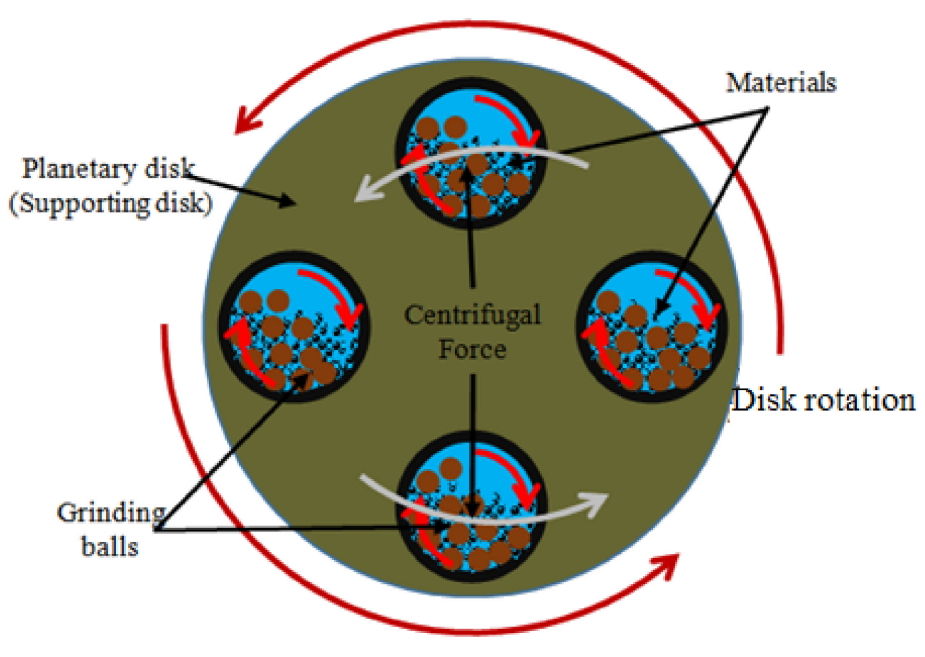

(b)

Fig. 2 Schematic diagram of (a) conventional ball milling, (b) Planetary Ball Milling.

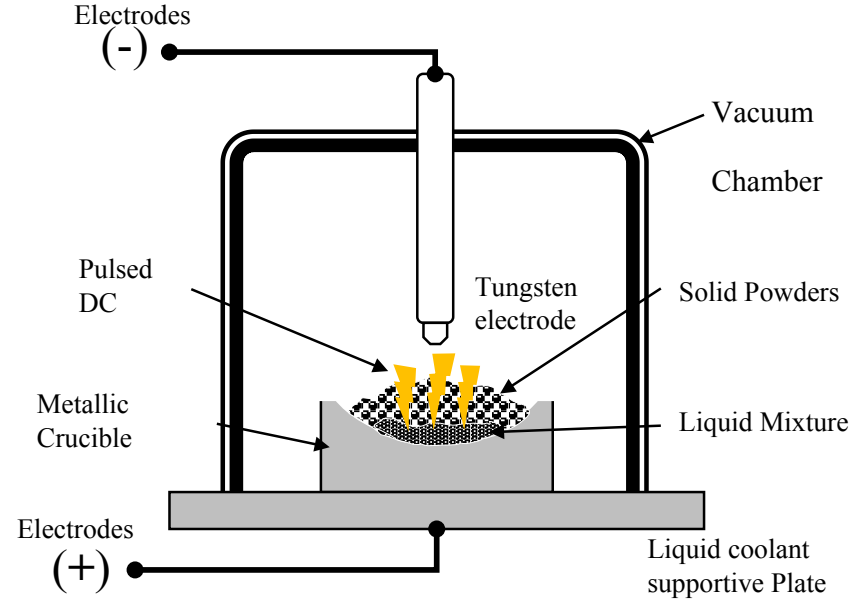

Fig. 3 A descriptive diagram of the arc melting Process.

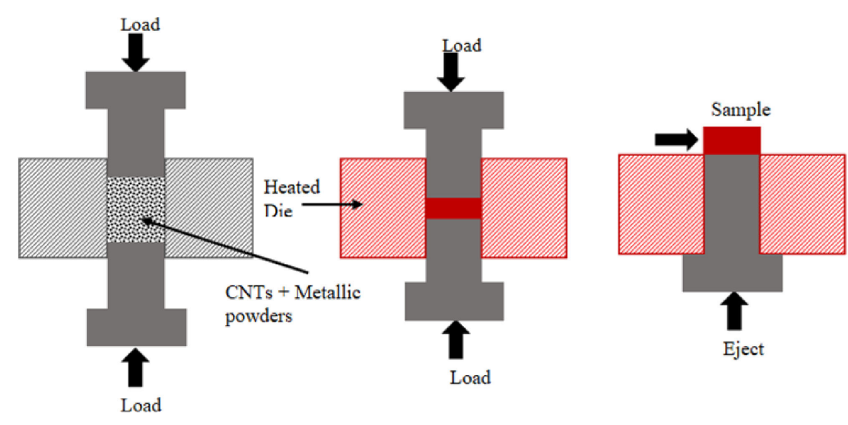

Fig. 5 Schematic diagram of a hot pressing process.

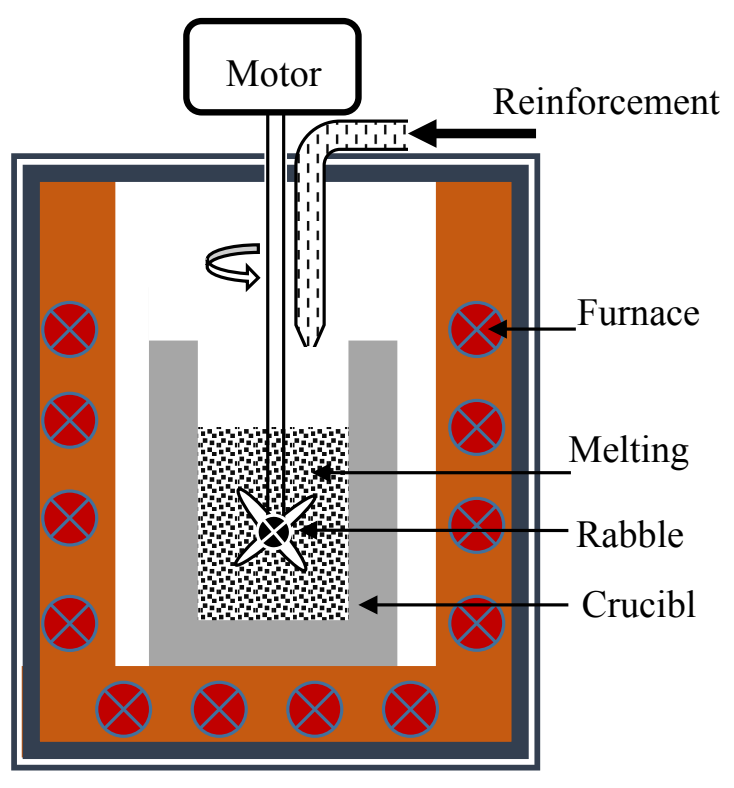

Fig. 4 Schematic diagram of mechanical stirring.

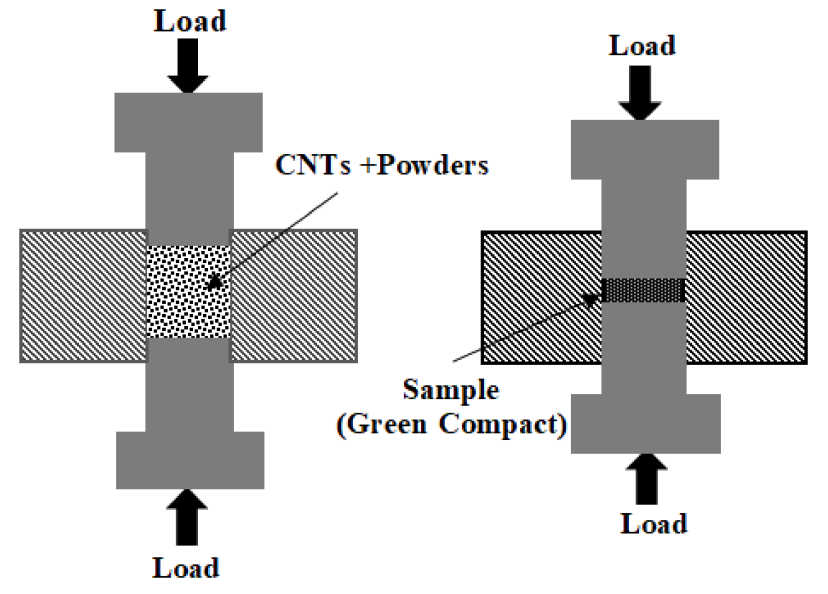

Fig. 6 Schematic diagram of a cold-pressing process. 


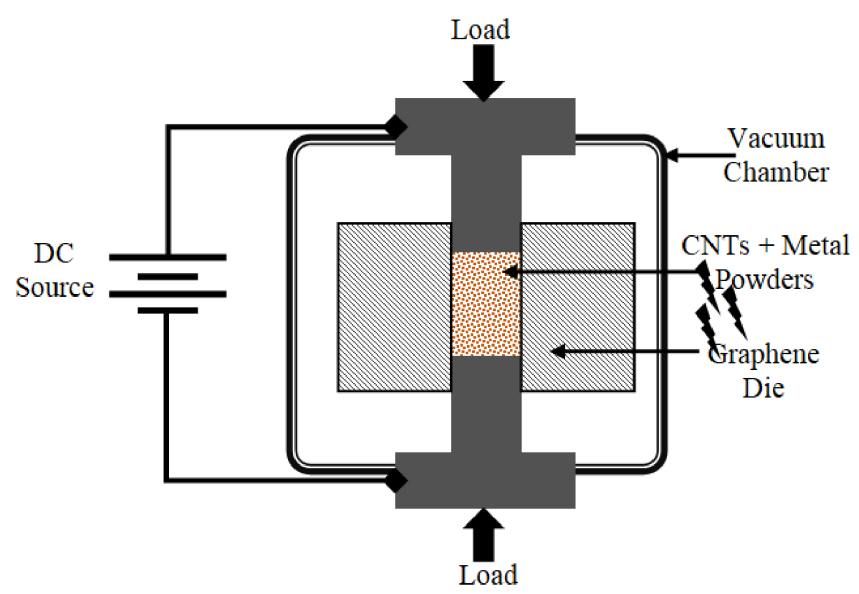

Fig. 7 Schematic diagram of Spark sintering plasma (SPS).

exposed the substantial impact of the interfacial shear stability and the influence of tube waviness on the damping performance of the CNT composite reinforced. Subsequently, Tsai et al. ${ }^{148)}$ suggested an enhanced surrogate model for checking the stability of CNT reinforced nanocomposites. They also utilized a set of data for MWCNT bison maleimide nanocomposite to study the usefulness of the suggested surrogate method. In conclusion, they calculated the theoretical composite modulus with micromechanical models and measured the experimental modulus by tensile tests. Their findings revealed an enhanced predictive ability in comparison with the traditional micromechanical model. The major target of Bhuiyan et al. ${ }^{149)}$ was to comprehend the reinforcing effectiveness of CNTs in polymers by using finite element modeling. The uniqueness of their work was that the possibility distribution function of CNT diameter, orientation, disposition and waviness, expected through graphic analysis, were integrated into the finite element model. Their graphic analysis technique used scanning electron microscopy (SEM) images of the CNT/polypropylene composites produced by melt mixing and injection modeling.

Laine et al. ${ }^{150)}$ primarily concentrated on sandwich structures produced with polymeric foam core reinforced to get their transverse shear stiffness. In their research, a numerical solution was produced taking into consideration a 2-D unit cell and using the basic principle of energy equivalence. Finally, they likened their numerical results with experimental values producing from three-point bending tests carried out with different volume fraction of reinforcements. By using a unique technique, Li et al. ${ }^{151)}$ manufactured CNTs reinforced $\mathrm{Mg}$ matrix composites. After hot extrusion, they checked out the effect of NTs on the microstructure and mechanical performance of an $\mathrm{Mg}-6 \mathrm{Zn}$ matrix. Their results confirmed that the majority of CNTs dispersed uniformly and separately in the composites, and great interfacial bonding was accomplished. In 2015, Alizadeh et al. ${ }^{152)}$ created specific composites reinforced with CNTs and boron carbide (B4C) by a powder metallurgy method. Also, they studied the surface roughness, wear resistance, hardness, and creep performance of the samples. They demonstrated that as B4C content raises, the hardness values of the composite improve. Additionally, the results of creep tests showed that the addition of NTs increases the creep rate of the A15083 alloy; however, adding B4C reduces its creep rate. Duarte et al. ${ }^{153)}$ introduced a novel technique to compose a novel class of closed-cell reinforced metal foams that synergistically is exploring the important properties of both metal foams and CNTs. Their microstructural analysis showed non-agglomerated, well distribution, stretched, and directionally aligned MWCNTs within the Al-matrix of the foams.

\subsection{Non-destructive testing}

The most significant non-destructive studies relating to the expectation of the mechanical behavior of reinforced composites are shown in this section. In 2003, Ning et al. ${ }^{154)}$ checked out the mechanical behavior of $\mathrm{SiO}_{2}$ matrix composites reinforced by CNTs. In their analysis, $\mathrm{SiO}_{2}$ glass powder and CNTs were mixed by ultrasonication in an ethanol solution. Also, they checked out the influence of the NTs content on the mechanical properties. Their major reinforcing methods consist of CNTs pulling out, crack defluxion and bridging. Finally, they detected some faults and aligning the orientation of CNTs in the matrix which were the affecting parameters on the mechanical properties of composites. Subsequently, Ruan et al. ${ }^{155)}$ documented the utilization of MWCNT to reinforce and toughen gel spun UHMWPE fibers. By using a mixture of high-resolution SEM and micro-Raman spectroscopy, they studied the mechanism of reinforcement. Finally, they established that the stability was enhanced via the bearing impact at the tensile strength.

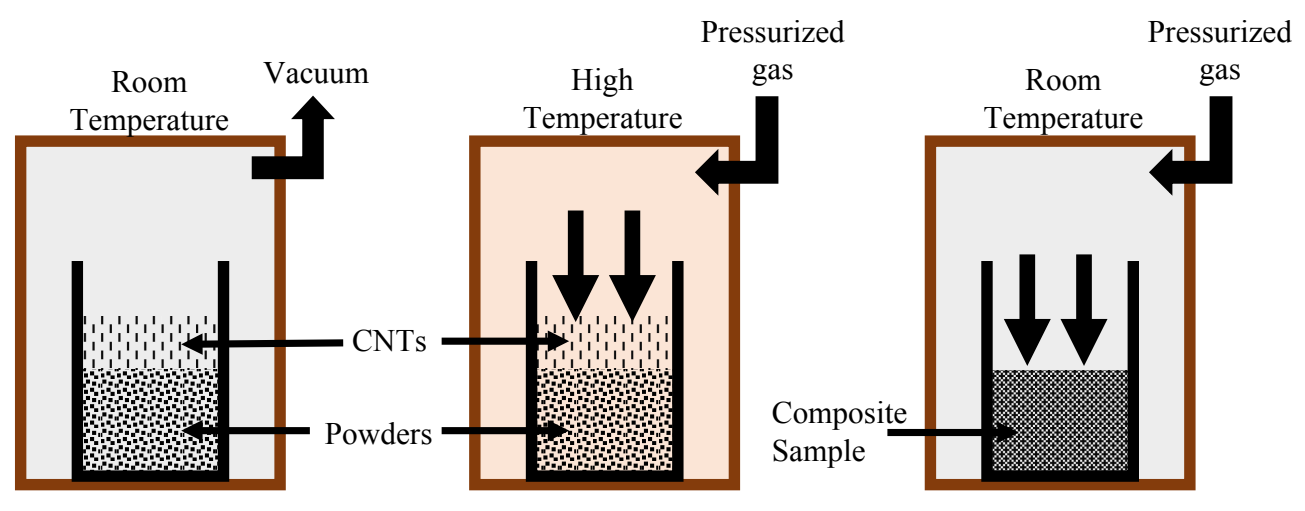

(1)

(2)

(3)

Fig. 8 Schematic diagram of the Infiltration method. 
Table 2 The comparisons between the results, type of reinforcement and matrix, the used technique, and the description techniques of CNTs.

\begin{tabular}{|c|c|c|c|c|c|c|}
\hline Ref. & $\begin{array}{l}\text { CNT } \\
\text { Type }\end{array}$ & $\begin{array}{c}\text { Dimensions } \\
\text { of CNTs }\end{array}$ & $\begin{array}{c}\text { Nanomaterial } \\
\text { (Matrix) }\end{array}$ & Technique's Name & Description & Results \\
\hline$[117]$ & MWCNTs & $\begin{array}{l}\text { Dia: } \\
\text { (8-15nm) } \\
\text { Length: } \\
(0.5-2 \mu \mathrm{m})\end{array}$ & $\mathrm{Cu}$ & $\begin{array}{l}\text { - Chemical vapor } \\
\text { deposition. } \\
\text { - Magnetic stirring } \\
\text { - Cold press process } \\
\text { - Microwave sintering } \\
\text { - Cold rolling process. } \\
\text { - Annealing process }\end{array}$ & $\begin{array}{l}\text { - The CNTs were acid treated in a } \\
\text { concentrated } \mathrm{H}_{2} \mathrm{SO}_{4} \text { and } \mathrm{HNO}_{3} \text { solution } \\
\text { at } 80{ }^{\circ} \mathrm{C} \text { for } 2 \mathrm{~h} \text {. then } \mathrm{CNTs} \text { were } \\
\text { sonicated for } 2 \mathrm{~h} \mathrm{in} \mathrm{distilled} \mathrm{water.} \\
\text { - Then, adding } \mathrm{Cu}\left(\mathrm{CH}_{3} \mathrm{COO}\right)_{2}, \mathrm{H}_{2} \mathrm{O} \text { into } \\
\text { the suspension and sonicated for } 2 \mathrm{~h} \text { to } \\
\text { form } \mathrm{CNTs} / \mathrm{Cu} \text { ion precursor. } \\
\text { - Then, the precursor was vaporized by } \\
\text { magnetic stirring at } 100^{\circ} \mathrm{C} \text { to get a dried } \\
\text { mixture which was calcined in air at } \\
350{ }^{\circ} \mathrm{C} \text { for } 1 \mathrm{~h} \text {. After that the mixture } \\
\text { was cold-pressed under the } 300 \mathrm{MPa} \\
\text { uniaxial pressure for } 120 \mathrm{~s} \text { then sintered } \\
\text { at } 1000{ }^{\circ} \mathrm{C} \text { for } 10 \text { min then furnace cool. } \\
\text { - After that, the samples were cold rolled } \\
\text { then annealed at } 600{ }^{\circ} \mathrm{C} \text { for } 2 \mathrm{~h} \text {. }\end{array}$ & $\begin{array}{l}\text { The subsequent rolling procedure } \\
\text { assists better microstructure and } \\
\text { performance of sintered composites } \\
\text { which displays a tensile strength of } \\
218 \mathrm{MPa} \text {, the elongation of } 37.75 \% \text {, } \\
\text { and the electrical conductivity of } \\
>98 \% \text { IACS compared to pure } \\
\text { copper }\end{array}$ \\
\hline [37] & MWCNTs & $\begin{array}{l}\text { Dia: } \\
(30-50 \mathrm{~nm}) \\
\text { Length: } \\
(1-2 \mu \mathrm{m})\end{array}$ & $\mathrm{Cu}-\mathrm{Ti}$ & $\begin{array}{l}\text { - Gas atomization } \\
\text { process } \\
\text { - Reduction process. } \\
\text { - Hot compaction } \\
\text { process (Hot-Press } \\
\text { process). }\end{array}$ & $\begin{array}{l}\text { - Alloy powders produced by gas } \\
\text { atomization. Then CNTs was mixed with } \\
\mathrm{Cu}-\mathrm{Ti} \text { alloy powders by low energy ball } \\
\text { milling at a rotation rate of } 150 \mathrm{rpm} \\
\text { for } 4 \mathrm{~h} \text {. } \\
\text { - Then, CNTs } / \mathrm{Cu}-\mathrm{Ti} \text { composite powders } \\
\text { were acquired by reduction at } 573 \mathrm{~K} \text { for } \\
2 \mathrm{~h} \text { in a hydrogen atmosphere. CNTs/Cu- } \\
\mathrm{Ti} \text { composite powders compacted in for } \\
30 \text { min at } 8500^{\circ} \mathrm{C} \text { and } 70 \mathrm{Mpa}\end{array}$ & $\begin{array}{l}\text { (Ultimate tensile strength (UTS) } \\
352 \mathrm{MPa} \text {, elongation } 28.2 \% \text {, the } \\
\text { UTS is } 39 \% \text { higher than that of the } \\
\mathrm{Cu}-\mathrm{Ti} \text { alloy, and the ductility } \\
\text { increased significantly by } 62 \% \text {.) }\end{array}$ \\
\hline$[118]$ & MWCNTs & $\begin{array}{l}\text { Dia: } \\
(15 \mathrm{~nm} \pm 5 \\
\mathrm{nm})\end{array}$ & $\begin{array}{l}(\mathrm{Cu}-1.0 \mathrm{Ti}) \\
\text { alloy powders }\end{array}$ & $\begin{array}{l}\text { - } \text { Molecular Level } \\
\text { Mixing (MLM) } \\
\text { - Magnetic stirring } \\
\text { process } \\
\text { - Ultrasonic dispersion } \\
\text { process. } \\
\text { - Gas atomization } \\
\text { process }\end{array}$ & $\begin{array}{l}\text { - The pristine CNTs was impregnated in } \\
\text { concentrated sulfuric acid and nitric acid } \\
\text { then heated in water for } 6 \mathrm{~h} \text { at } 60^{\circ} \mathrm{C} \text { the } \\
\text { dried for } 24 \mathrm{~h} \text { at } 250{ }^{\circ} \mathrm{C} \text {. } \\
\text { - Ultrasonic dispersion process takes a } \\
\text { place to impregnated the CNTs in } \\
\text { deionized water. CuAc was dissolved in } \\
\text { water and stirred for } 30 \text { min the CNTs } \\
\text { added to CuAc and heated in water for } 5 \\
\text { min at } 75{ }^{\circ} \mathrm{C} \text {. After that, } 4 \text { Mole of } \\
\mathrm{NaOH} \text { was added then stirring for } 10 \\
\text { min and add } 2 \text { Mole of glucose. The } \\
\mathrm{CNTs} / \mathrm{Cu} 2 \mathrm{O} \text { was successfully obtained. } \\
\text { - Cu-1.0Ti alloy powders were ball milled } \\
\text { in alcohol for } 10 \mathrm{~h} \text { and } 300 \text { rpm. } \\
\mathrm{CNTs} / \mathrm{Cu} 2 \mathrm{O} \text { mixed with flaked alloy } \\
\text { powders by ball milling for } 2 \mathrm{~h} \text { but low } \\
\text { energy. The mixture was hot pressed at } \\
50 \mathrm{MPa} \text { and } 800^{\circ} \mathrm{C} \text { for } 30 \text { min. }\end{array}$ & $\begin{array}{l}\text { Better dispersion, higher } \\
\text { compatibilities of the matrix with } \\
\text { CNTs, and enhanced interfacial } \\
\text { bonding make } 0.8 \% \text { CNTs } / \mathrm{Cu}-\mathrm{Ti} \\
\text { composites exhibit the increments } \\
\text { of UTS being } 35.15 \% \text {, }\end{array}$ \\
\hline [119] & MWCNTs & & $\begin{array}{l}\text { Iron powder } \\
(20-200 \mu \mathrm{m})\end{array}$ & $\begin{array}{l}\text { - Ball milling process } \\
\text { - Cold Compaction } \\
\text { - Sintering process }\end{array}$ & $\begin{array}{l}\text { - The iron powder and CNT, with liquid } \\
\text { paraffin used as a binder, is blended by } \\
\text { the ball milling process. } \\
\text { - After that, the powder was compacted in } \\
\text { a hydraulic press. } \\
\text { - The compacted sample, named green } \\
\text { sample, was sintered with a Nitrogen } \\
\text { atmosphere. } \\
\text { - The sintered component with the various } \\
\text { composition of CNT is fabricated. }\end{array}$ & $\begin{array}{l}\text { - As carbon nanotube increase the } \\
\text { compressive strength of the } \\
\text { material also improved. } 0.75 \\
\text { wt. \% CNT yield a maximum } \\
\text { compressive strength of } 745 \mathrm{MPa} \text {. } \\
\text { - For } 0.75 \text { wt. } \% \text { CNT have the high } \\
\text { hardness value } 423 \mathrm{HV} \text { compared } \\
\text { to pure Fe which is } 328.66 \text {. }\end{array}$ \\
\hline$[120]$ & MWCNTs & & $\begin{array}{l}\text { Powders of } \\
\text { aluminum }(22 \\
\pm 11 \mu \mathrm{m})\end{array}$ & $\begin{array}{l}\text { - Dispersion ultrasonic } \\
\text { bath. } \\
\text { - Dispersion } \\
\text { ultrasonication } \\
\text { - Dispersion and } \\
\text { mixing } \\
\text { ultrasonication } \\
\text { - Cold press process } \\
\text { - Sintering process }\end{array}$ & $\begin{array}{l}\text { - Route 1: The CNT were dispersed in } \\
\text { ethanol using an ultrasonic bath for } 15- \\
90 \mathrm{~min} \text {. The CNTs were mixed with } \mathrm{Al} \\
\text { powders in a Turbula for } 60-600 \mathrm{~min} \text {. } \\
\text { - Route 2: the CNT were dispersed in } \\
\text { isopropanol by ultrasonication for } 15- \\
60 \text { min at } 20,400 \mathrm{kHz} \\
\text { - Route 3: The CNT and Al powders were } \\
\text { ultrasonicated in isopropanol for } 15 \text { to } 60 \\
\text { min at } 20,400 \mathrm{kHz} \\
\text { - After that The materials were uniaxially } \\
\text { pressed with } 100 \text { to } 300 \mathrm{MPa} \text { and } \\
\text { sintered at } 500 \text { to } 640{ }^{\circ} \mathrm{C} \text { for } 30 \text { to } 90 \\
\text { min in a vertical furnace under a } \\
\text { vacuum. }\end{array}$ & $\begin{array}{l}\text { Nano-composites with } 0.75 \text { wt. } \% \text { of } \\
\text { CNT exhibit well dispersed and } \\
\text { embedded nanotubes and the } \\
\text { highest hardness and tensile strength } \\
50 \mathrm{HV} \text { and } 196 \mathrm{Mpa} \text { respectively. } \\
\text { The observed } 200 \% \text { increase in the } \\
\text { tensile strength attested }\end{array}$ \\
\hline [121] & MWCNTs & Dia: & Aluminum & - Ball milling process & - Aluminum powders and CNT were & There was no improvement in \\
\hline
\end{tabular}

Continued on next page.

Subsequently, Rokni et al. ${ }^{156)}$ suggested a new principle for enhancing the dynamic response of composite structures. Based on the obtained optimum distribution, they created composite plates and evaluated their effective stiffness, constituent frequencies, and damping ratios by means of free vibration and static deflection tests. They established that the optimum distribution of NTs lead in an increase of $10.4 \%$ and $21.9 \%$ in the fundamental damped natural frequency values and the efficient Young's modulus, respectively.

Park et al. ${ }^{157)}$ carried out a research on explaining 
Continued.

\begin{tabular}{|c|c|c|c|c|c|c|}
\hline & & $\begin{array}{l}(10-30 \mathrm{~nm}) \\
\text { Length: } \\
(15-30 \mu \mathrm{m})\end{array}$ & $(74 \mu \mathrm{m})$ & $\begin{array}{l}\text { - Cold pressing process } \\
\text { - Sintering process }\end{array}$ & $\begin{array}{l}\text { blended by a ball-milling process for } 30 \\
\text { min using steel balls at } 400 \mathrm{rpm} \text {. } \\
\text { - Then compacted under a load of } 150 \mathrm{kN} \\
\text { then the green samples sintered. }\end{array}$ & $\begin{array}{l}\text { hardness of the composite on the } \\
\text { addition of CNT. The compressive } \\
\text { strength of the composite was } \\
\text { increased by } 143.58 \mathrm{MPa}\end{array}$ \\
\hline [91] & MWCNTs & $\begin{array}{l}\text { Dia: } \\
(15-35 \mathrm{~nm})\end{array}$ & $\begin{array}{l}\text { Powders of } \\
\text { aluminum }(50- \\
60 \mu \mathrm{m})\end{array}$ & $\begin{array}{l}\text { - Ultrasonication } \\
\text { process } \\
\text { - Ball milling process }\end{array}$ & $\begin{array}{l}\text { - The CNTs were untangled previously by } \\
\text { ultrasonication in propanol for } 15 \text { min. } \\
\text { - And, then mixed with } \mathrm{Al} \text { powders by } \\
\text { ball milling in propanol during } 6 \mathrm{~h} \text {. }\end{array}$ & $\begin{array}{l}\text { The use of ball milling for mixing } \\
\text { CNTs with Al powders can improve } \\
\text { the CNTs dispersion by reducing } \\
\text { the size of the agglomerates. }\end{array}$ \\
\hline [92] & MWCNTs & $\begin{array}{l}\text { Dia } \\
(19-25 \mathrm{~nm})\end{array}$ & $\begin{array}{l}\text { Aluminum } \\
\text { powders } \\
(65 \mu \mathrm{m}) \\
\text { Nickel } \\
\text { powders } \\
(60 \mu \mathrm{m})\end{array}$ & $\begin{array}{l}\text { using ultrasonication as } \\
\text { the dispersion }\end{array}$ & $\begin{array}{l}\text { - The MWCNTs were dispersed and } \\
\text { mixed with metallic powders in } \\
\text { isopropanol using an ultrasonicator for } \\
15 \mathrm{~min} \text {. } \\
\text { - Then, the mixtures were dried and } \\
\text { uniaxially pressed with } 300 \mathrm{MPa} \text { for } \\
\text { Al/CNTs and } 900 \mathrm{MPa} \text { for } \mathrm{Ni} / \mathrm{CNTs} \text {. } \\
\text { - After that, the sintering process was } \\
\text { applied for the samples at } 640{ }^{\circ} \mathrm{C} \text { for } 90 \\
\text { min under a vacuum atmosphere. }\end{array}$ & $\begin{array}{l}\text { The better dispersion results were } \\
\text { observed for the nanocomposites } \\
\text { produced with } 1.00 \text { vol } \% \text { of CNTs } \\
\text { leading to the highest hardness } \\
\text { values. The } 50 \% \text { hardness increase } \\
\text { demonstrated the strengthening } \\
\text { effect of the CNTs }\end{array}$ \\
\hline [122] & CNTs & $\begin{array}{l}\text { Dia: } \\
(60-100 \mathrm{~nm}) \\
\text { Length: } \\
(5-15 \mu \mathrm{m})\end{array}$ & Al powders & $\begin{array}{l}\text { - Solution ball milling } \\
\text { (SBM) } \\
\text { - Spark Plasma } \\
\text { Sintering Process }\end{array}$ & $\begin{array}{l}\text { The isopropyl alcohol (IPA) based solution } \\
\text { with }-1 \text { wt.\% zwitterionic surfactants [18] } \\
\text { was used to obtain } 1 \text { wt. } \% \text { CNT solution } \\
\text { Then, the al powder and CNTs were mixed } \\
\text { using a planetary ball milling machine } \\
\text { with a speed of } 200 \mathrm{rpm} \text { for } 60 \text { min } \\
\text { Then, dried in an oven at } 353 \mathrm{~K} \text { for } 30 \\
\text { min. after that, the sparking plasma } \\
\text { sintering process at a temperature of } \\
600{ }^{\circ} \mathrm{C} \text { for } 30 \text { min and pressure of } 30 \mathrm{MPa} \\
\text { was applied followed by hot extrusion. }\end{array}$ & $\begin{array}{l}\text { The tensile strength of the Al matrix } \\
\text { was noticeably enhanced by CNT } \\
\text { additions agreeing with the potential } \\
\text { strengthening effect predicted by the } \\
\text { load transfer mechanism. }\end{array}$ \\
\hline [93] & MWCNTs & $\begin{array}{l}\text { Dia: } \\
(10 \mathrm{~nm}) \\
\text { Length: } \\
(5 \mu \mathrm{m})\end{array}$ & $\begin{array}{l}\text { Al-5Mg } \\
(\text { Dia: } 10 \mu \mathrm{m})\end{array}$ & $\begin{array}{l}\text { - Ball milling process. } \\
\text { - Cold-Compaction. } \\
\text { - Hot-press process. } \\
\text { - Hot extrusion process } \\
\text { - Annealing process }\end{array}$ & $\begin{array}{l}\text { - CNTs were ball milled with Al-5Mg } \\
\text { alloy powders at } 300-450 \text { rpm for } 2-8 \mathrm{~h} \text {. } \\
\text { - The mixture cold-compacted in a } \\
\text { cylinder die, degassed and hot-pressed at } \\
753 \mathrm{~K} \text { for } 1 \mathrm{~h} \text { then the samples were hot } \\
\text { extruded at } 723 \mathrm{~K} \text {. CNT/Al-5Mg } \\
\text { composites was annealed at } 753 \mathrm{~K} \text { for } 1- \\
4 \mathrm{~h} \\
\text { - Then, room cooling. }\end{array}$ & $\begin{array}{l}\text { The elastic modulus of the CNT/Al- } \\
5 \mathrm{Mg} \text { composites increased as CNT } \\
\text { concentration increased, which can } \\
\text { be predicted by the Tsai-Halpin } \\
\text { equation. The tensile strength of the } \\
\text { composites showed a significant } \\
\text { increase compared with the matrix } \\
\text { alloy. }\end{array}$ \\
\hline [86] & $\begin{array}{l}\text { Graphene } \\
\text { nanosheet } \\
\text { s } \\
\text { GNSs }\end{array}$ & & $\mathrm{Cu}$ powders & $\begin{array}{l}\text { - Hummers' method } \\
\text { - Ball milling process } \\
\text { - Hot-press sintering } \\
\text { process. }\end{array}$ & $\begin{array}{l}\text { - The GO nanosheets were dispersed in } \\
\text { ethanol for } 1 \mathrm{~h} \text { by the ultrasonic process } \\
\text { then added Cu powder. } \\
\text { - The mixed powders were obtained in the } \\
\text { vacuum drying oven at } 80^{\circ} \mathrm{C} \text { for } 24 \mathrm{~h} \text { to } \\
\text { remove ethanol. } \\
\text { - After that, the mixture ball-milled at a } \\
\text { rotation rate of } 400 \mathrm{rpm} \text { in an argon } \\
\text { atmosphere. } \\
\text { - Then, the mixture was pressed and } \\
\text { sintered simultaneously at } 25 \mathrm{MPa} \text { and } \\
850^{\circ} \mathrm{C} \text { for } 1 \mathrm{~h} \text { in a vacuum atmosphere. }\end{array}$ & $\begin{array}{l}\text { When the content of GNSs in the } \\
\text { composite is } 0.5 \mathrm{wt} \% \text {, the UTS and } \\
\mathrm{d} \text { of the composite are the highest. } \\
\text { The fracture mechanism changes } \\
\text { from ductile to brittle with } \\
\text { increasing the GNS contents }\end{array}$ \\
\hline [115] & GNSs & $\begin{array}{l}\text { Dia: } \\
7.05 \mu \mathrm{m}\end{array}$ & $\begin{array}{l}\text { Al6063 } \\
\text { powder } \\
\text { (Dia: } 4.7 \mu \mathrm{m} \text { ) }\end{array}$ & $\begin{array}{l}\text { - High energy ball } \\
\text { milling process } \\
\text { - Compaction process. } \\
\text { - Pressure Infiltration. } \\
\text { - Hot Extrusion process }\end{array}$ & $\begin{array}{l}\text { - Adding The GNSs/Al6063 composite } \\
\text { with } 500 \mathrm{ml} \text { volume zirconia vial into } \\
\text { planetary ball milling machine for } 1 \text { to } 4 \\
\text { hours at a velocity of } 150 \mathrm{rpm} \text {. } \\
\text { - After that, The mixture was pre- } \\
\text { compacted and preheated for } 700^{\circ} \mathrm{C} \text {. } \\
\text { - Then, a hot-extrusion process was } \\
\text { applied. }\end{array}$ & $\begin{array}{l}\text { The Highest tensile strength of } 276 \\
\mathrm{MPa} \text { was obtained only with } 0.3 \\
\mathrm{wt} \% \text { GNSs, which was } 22.5 \% \\
\text { enhancement over the unreinforced } \\
\text { Al matrix with the same preparation } \\
\text { process and no decrease in } \\
\text { elongation. }\end{array}$ \\
\hline [123] & MWCNTs & $\begin{array}{l}\text { Dia: } \\
18 \mathrm{~nm} \\
\text { length: } \\
1.6-2.2 \mu \mathrm{m}\end{array}$ & $\mathrm{Cu}_{2} \mathrm{O}$ & $\begin{array}{l}\text { - Microwave plasma } \\
\text { chemical vapor } \\
\text { (MPCVD) method. } \\
\text { - Deposition. } \\
\text { - Ultrasonic with } \\
\text { isopropylalcohol. } \\
\text { - Sintering process. }\end{array}$ & $\begin{array}{l}\text { - Ultrasonic for } 20 \mathrm{~min} \text { to agitate the } \\
\mathrm{CNTs} \text { in isopropylalcohol (IPA) for } 20 \\
\text { min. } \\
\text { - Then, immersing in a solution of } \\
\mathrm{H} 2 \mathrm{SO} 4 / \mathrm{HNO} 3(3: 1 \mathrm{ratio} \text { ) in order to } \\
\text { produce active sites for subsequent } \\
\text { reaction with the } \mathrm{Cu} \text { ions. } \\
\text { - Then, add } \mathrm{Cu}(\mathrm{ac}) \mathrm{H} 2 \mathrm{O} \text {, Aldrich then } \\
\text { sealed and purged in an argon-protected } \\
\text { environment for } 2 \mathrm{~h} \text {. }\end{array}$ & $\begin{array}{l}\text { - Mechanical responses (critical } \\
\text { strength and hardness) of the } \\
\mathrm{CNT} / \mathrm{Cu} \text { composites depend on } \\
\text { both the matrix grain size and the } \\
\mathrm{CNT} \text { content. } \\
\text { - However, of the two factors, the } \\
\text { enhanced mechanical response is } \\
\text { dominated by CNT addition rather } \\
\text { than grain size reinforcement } \\
\text { - Addition of CNTs to the Cu } \\
\text { matrix improves the wear } \\
\text { resistance by a minimum of } 40 \% \\
\text { compared to that of a pure } \mathrm{Cu} \\
\text { sample }\end{array}$ \\
\hline [124] & CNTs & $\begin{array}{l}\text { Dia: } \\
\text { 20-40 nm } \\
\text { Length: } \\
10-30 \mu \mathrm{m}\end{array}$ & $\begin{array}{l}\mathrm{Cu} \\
\text { thickness: } \\
100-120 \mu \mathrm{m}\end{array}$ & $\begin{array}{l}\text { - Composite } \\
\text { electrodeposition } \\
\text { - Spark plasma } \\
\text { sintering (SPS) }\end{array}$ & $\begin{array}{l}\text { - The CNT dispersant was composed of } 10 \\
\text { wt } \% \text { of CNTs, non-ionic surfactants, and } \\
\text { H2O. } \\
\text { - Two copper plates were used as the }\end{array}$ & $\begin{array}{l}\text { The YS and UTS of the composites } \\
\text { deposited under a current density of } \\
1 \mathrm{~A} \cdot \mathrm{dm}-2 \text { are } 128 \mathrm{MPa} \text { and } 244 \\
\mathrm{MPa} \text {, respectively, which }\end{array}$ \\
\hline
\end{tabular}

Continued on next page.

numerous mechanisms such as the generation of dislocations from the thermal mismatch, the Orowan looping system, and load transfer for clarifying the enhanced characteristics of CNTs reinforced Aluminum. The formulation of covalent bonds between Aluminum and CNTs walls was verified by Raman spectroscopy, transmission electron microscopy (TEM), and X-ray diffraction measurements. Subsequently, Wang et al. ${ }^{158)}$ researched the relationship between the filler 
Continued.

\begin{tabular}{|c|c|c|c|c|c|c|}
\hline & & & & $\begin{array}{l}\text { - Cold pressing process } \\
\text { - Sintering process }\end{array}$ & $\begin{array}{l}\text { anodes and a titanium plate was used as } \\
\text { the cathode. } \\
\text { - The as-prepared films, with a thickness } \\
\text { of } 100-120 \mu \mathrm{m} \text {, were cut into circles } \\
\text { with a diameter of } 20 \mathrm{~mm} \text {. } \\
\text { - Then, cold pressing was applied then } \\
\text { sintered under vacuum. }\end{array}$ & \\
\hline [108] & MWCNTs & $\begin{array}{l}\text { Dia: } \\
9.5 \mathrm{~nm} \\
\text { Length: } \\
1.5 \mu \mathrm{m}\end{array}$ & $\begin{array}{l}6063 \mathrm{Al} \text { alloy } \\
\text { powders Dia: } \\
94 \mu \mathrm{m}\end{array}$ & $\begin{array}{l}\text { - Powder metallurgy } \\
\text { process } \\
\text { - Spark plasma } \\
\text { sintering (SPS) } \\
\text { - Hot extrusion }\end{array}$ & $\begin{array}{l}\text { - A6063 raw powders were mixed with } \\
\text { isopropyl alcohol (IPA) solution } \\
\text { containing } 1 \text { wt. } \% \text { un-bundled CNTs, } \\
\text { - And the elemental mixture slurries were } \\
\text { stirred in the pot. } \\
\text { - Then, CNTs coated Al alloy composite } \\
\text { powders were compacted into the } \\
\text { columnar billet via spark plasma } \\
\text { sintering (SPS) process fat } 550{ }^{\circ} \mathrm{C} \text { for } \\
30 \text { mins under the pressure of } 30 \mathrm{MPa} \text { in a } \\
\text { vacuum. } \\
\text { - Then, hot extruded. }\end{array}$ & $\begin{array}{l}\text { - The as-extruded composite } \\
\text { materials with } 0.56 \text { and } 1.22 \\
\text { vol.\% CNTs reveal yield stress } \\
\text { (YS) of } 134.5 \text { and } 135.2 \mathrm{MPa} \\
\text { respectively. There is a very small } \\
\text { difference in YS in the composite } \\
\text { between } 0.56 \text { and } 1.22 \text { vol.\% } \\
\text { CNTs. } \\
\text { - In addition, they indicate a small } \\
\text { increment of mechanical strength } \\
\text { compared to the monolithic alloy } \\
\text { with no CNT reinforcement } \\
\text { showing 128.7 MPa YS. }\end{array}$ \\
\hline [125] & $\begin{array}{l}\text { MWCNTs } \\
\text {-(type A) } \\
\text {-(type B) }\end{array}$ & $\begin{array}{l}\text { Dia(A): } \\
\text { 15nm } \\
\text { Length(A): } \\
0.5-1 \mu \mathrm{m} . \\
\text { Dia(B): } \\
\text { 40nm } \\
\text { Length(B): } \\
3-10 \mu \mathrm{m} .)\end{array}$ & $\begin{array}{l}\text { Pure Mg } \\
\text { (99.5\% purity) } \\
\text { AZ31B Mg } \\
\text { alloy powder }\end{array}$ & $\begin{array}{l}\text { - Ultra-sonic vibration } \\
\text { - The de-binding } \\
\text { process was } \\
\text { - Spark plasma } \\
\text { sintering } \\
\text { - Hot extrusion }\end{array}$ & $\begin{array}{l}\text { - Ultrasonic vibration was used to disperse } \\
\text { the agglomerated CNTs in ethanol, } \\
\text { followed by dipping powder into a } \\
\text { zwitterionic surfactant solution, } \\
\text { - And subsequently dried in the oven at } \\
353 \mathrm{~K} \text { for } 10.8 \mathrm{ks} \text { in an argon gas } \\
\text { atmosphere. } \\
\text { - Each powder coated with CNTs was } \\
\text { consolidated by a spark plasma sintering } \\
\text { process. } \\
\text { - The samples were heated at } 673 \mathrm{~K} \text { for } \\
180 \mathrm{~s} \text { in argon gas, and immediately put } \\
\text { through hot extrusion. }\end{array}$ & $\begin{array}{l}\text { When approximately 1vol.\% CNTs } \\
\text { were added, the extruded pure Mg } \\
\text { and AZ31B alloy composites } \\
\text { displayed an extremely large } \\
\text { increase of the tensile yield stress of } \\
25-40 \% \text {, compared to Mg materials } \\
\text { containing no CNT. } \\
\text { the elongation was less than } 5 \% \text {, } \\
\text { and the composites exhibited a very } \\
\text { poor ductility }\end{array}$ \\
\hline [102] & $\begin{array}{l}\text { graphene } \\
\text { nanosheet } \\
\mathrm{s} \text { (GNS) }\end{array}$ & & $\begin{array}{l}\text { AZ91 alloy } \\
\text { powders } \\
70 \mu \mathrm{m} \text { and } \\
99.9 \% \text { in } \\
\text { purity. }\end{array}$ & $\begin{array}{l}\text { - Modified Hummers } \\
\text { method } \\
\text { - Ultra-sonic vibration } \\
\text { - hyper mechanical- } \\
\text { stirring and ultrasonic } \\
\text { process. } \\
\text { - Press process } \\
\text { - Sintering process } \\
\text { - Hot extrusion }\end{array}$ & $\begin{array}{l}\text { - The GNS were dispersed into ethanol by } \\
\text { ultrasonication for } 2 \mathrm{~h} \text {. } \\
\text { - AZ91 powders were added in ethanol } \\
\text { under the argon atmosphere with the } \\
\text { following ultrasonication for } 30 \mathrm{~min} \text { to } \\
\text { obtain a suspension of AZ91 powders. } \\
\text { - The ultrasonicated GNS solution was } \\
\text { slowly dropped into the suspension of } \\
\text { AZ91 powders. } \\
\text { - Then, it followed by pressing, sintering } \\
\text { and hot extrusion. }\end{array}$ & $\begin{array}{l}\text { Filling } 0.5 \text { wt. } \% \text { of GNS, the yield } \\
\text { strength and elongation of the } \\
\text { composite increased by } 76.2 \% \text { and } \\
24.3 \% \text {, respectively as compared to } \\
\text { the matrix alloy }\end{array}$ \\
\hline [109] & MWCNTs & $\begin{array}{l}\text { Dia: } \\
\text { 5-30 nm } \\
\text { Length: } \\
1-10 \mu \mathrm{m}\end{array}$ & $\begin{array}{l}\text { AZ91 alloy } \\
\text { powders } \\
75 \mu \mathrm{m} \text { and } \\
99.5 \% \text { in } \\
\text { purity. }\end{array}$ & $\begin{array}{l}\text { - Ultrasonication } \\
\text { process. } \\
\text { - Mechanical stirring } \\
\text { process } \\
\text { - Mechanical mixing } \\
\text { process } \\
\text { - Sintering process } \\
\text { - Hot extrusion }\end{array}$ & $\begin{array}{l}\text { - First, metal powders were mixed in } \\
\text { ethanol solvent using a mechanical } \\
\text { agitator under atmospheric air. } \\
\text { - Second, MgO@CNTs were dispersed } \\
\text { into ethanol by ultrasonication for } 2 \mathrm{~h} \text {. } \\
\text { - Then } \mathrm{MgO} @ \mathrm{CNT} \text { and AZ91 were then } \\
\text { mixed together and mechanically stirred } \\
\text { for } 1 \mathrm{~h} \text { to form AZ91-MgO@CNT } \\
\text { composite suspension, which was } \\
\text { filtered and dried at } 313 \text { Kunder vacuum } \\
\text { for } 12 \mathrm{~h} \text {. } \\
\text { - Then, the mixtures were compacted in a } \\
40 \mathrm{~mm} \text { wide and } 200 \text { mm hight cylinder } \\
\text { mold under a hydraulic pressure of } 120 \\
\text { MPa then sintered in a tube furnace at } \\
873 \mathrm{~K} \text { for } 2 \mathrm{~h} \text { under Ar atmosphere then } \\
\text { hot extrusion was applied. }\end{array}$ & $\begin{array}{l}\text { The yield strength and elongation of } \\
\text { AZ91-3.0MgO@CNT composite } \\
\text { were enhanced by } 69.0 \% \text { and } \\
22.9 \% \text {, respectively, when } \\
\text { compared with the AZ91 alloy }\end{array}$ \\
\hline [110] & MWCNTs & $\begin{array}{l}\text { Dia: } \\
20 \mathrm{~nm} \\
\text { Length: } \\
5 \mu \mathrm{m}\end{array}$ & $\begin{array}{l}\text { Al2024 } \\
\text { powder } \\
(99.5 \% \text { purity) }\end{array}$ & $\begin{array}{l}\text { - High-energy ball } \\
\text { milling } \\
\text { - Cold /hot press } \\
\text { - Sintering }\end{array}$ & $\begin{array}{l}\text { - The ball-to-powder weight ratio was } \\
15: 1 \text {, and the chamber was stirred by } \\
\text { horizontal impellers attached to a } \\
\text { vertical shaft rotating at a controlled } \\
\text { speed of } 500 \mathrm{RPM} \text { for } 5 \mathrm{~h} \text { in which } \\
\text { water was circulated in the chamber } \\
\text { surface. } \\
\text { - Then uniaxial cold Press process at } 560 \\
\text { MPa for } 10 \text { min in a cylindrical mold. } \\
\text { - For hot pressing, the mixture was press } \\
\text { into the mold at } 375 \mathrm{MPa} \text { and } 530 \mathrm{oC} \text { for } \\
1.5 \mathrm{~h} \text {. } \\
\text { - Then, sintering at } 500{ }^{\circ} \mathrm{C} \text { for } 24 \mathrm{~h} \text {. }\end{array}$ & $\begin{array}{l}\text { Tensile and fatigue strength of the } \\
\text { Al2024/MWCNT composites } \\
\text { increases with increasing the } \\
\text { MWCNT content. Al2024/4 vol.\% } \\
\text { MWCNT composite shows the } \\
\text { notably enhanced fatigue strength of } \\
600 \mathrm{MPa} \text { at } \\
\text { the } 2.5 ? 106 \text { cycles and the ratio of } \\
\text { tensile strength to fatigue strength } \\
\text { of } 0.78 \text {. }\end{array}$ \\
\hline [111] & MWCNTs & $\begin{array}{l}\text { Dia: } \\
5-20 \mathrm{~nm}\end{array}$ & $\begin{array}{l}\text { Aluminum } \\
\text { alloy AA5083 }\end{array}$ & $\begin{array}{l}\text { - Compo-casting } \\
\text { method }\end{array}$ & $\begin{array}{l}\text { Compo-casting were used to produce the } \\
\text { composite with uniformly dispersed }\end{array}$ & $\begin{array}{l}\text { Hardness increased from } 74 \mathrm{BHN} \\
\text { for the alloy AA5083 to } 84 \mathrm{BHN} \text { for }\end{array}$ \\
\hline
\end{tabular}

Continued on next page.

orientation and the resulting relative permittivity of nanocomposites reinforced models to achieve an appropriate forecast of the efficient dielectric constant. It was established that the orientation angle factor along the applied electric field is the major parameter to figure out the efficient dielectric constants. Furthermore, a comparison between the proposed experimental data and random orientation models were carried out to clarify the ability of the suggested models. 
Continued.

\begin{tabular}{|c|c|c|c|c|c|c|}
\hline & & $\begin{array}{l}\text { Length: } \\
1-10 \mu \mathrm{m}\end{array}$ & & & $\begin{array}{l}\text { MWCNT reinforcement in Aluminium } \\
\text { alloy AA5083 using stir casting apparatus. }\end{array}$ & $\begin{array}{l}1.75 \mathrm{wt} \% \text { of reinforced composite } \\
\text { and considerably increased for } 1 \text {, } \\
1.25 \text { and } 1.5 \mathrm{wt} \% \text { addition of } \\
\text { MWCNT. } \\
\text {-AA5083/MWCNT composite have } \\
\text { better corrosion resistance than the } \\
\text { AA5083 alloy in } \mathrm{HCl} \text { (dil) at room } \\
\text { temperature }\end{array}$ \\
\hline [126] & CNT & & $\begin{array}{l}\text { Pure } \mathrm{Al} \\
\text { powders }(-200 \\
\text { mesh }\end{array}$ & $\begin{array}{l}\text { - In-situ chemical } \\
\text { vapor deposition. } \\
\text { - Powder metallurgy }\end{array}$ & $\begin{array}{l}\text { Combination of in-situ chemical vapor } \\
\text { deposition and powder metallurgy using } \\
\text { titanium hydride as a blowing agent to } \\
\text { produce Al alloy foam with the } \\
\text { improvement of the pore uniformity and } \\
\text { reduction of the pore size. }\end{array}$ & $\begin{array}{l}\text { The plateau stress (average stress } \\
\text { between } 20 \% \text { and } 40 \% \text { strain) is } \\
\text { enhanced from } 14.98 \mathrm{MPa} \text { to } \\
29.25 \mathrm{MPa} \text { while the energy } \\
\text { absorption capacity }(50 \% \text { strain) } \\
\text { rises from } 7.06 \mathrm{MJ} / \mathrm{m} 3 \text { to } 13.66 \\
\mathrm{MJ} / \mathrm{m}^{3} \text {. }\end{array}$ \\
\hline [127] & MWCNTs & $\begin{array}{l}\text { Dia: } \\
\text { 10-30 nm } \\
\text { Length: } \\
1-10 \mu \mathrm{m}\end{array}$ & $\begin{array}{l}\mathrm{Cu}-10 \mathrm{Sn} \text { alloy } \\
\text { powder }\end{array}$ & $\begin{array}{l}\text { - Ball milling, } \\
\text { - Compaction of the } \\
\text { composite powder } \\
\text { - Sintering } \\
\text { - Repressing. }\end{array}$ & $\begin{array}{l}\text { - The } \mathrm{Cu}-\mathrm{Sn} \text { alloy powder and each mass } \\
\text { fraction of CNTs were balls milled in a } \\
\text { planetary ball mill at } 200 \mathrm{r} / \mathrm{min} \text {. } \\
\text { - The mass ratio of the ball to powder is } \\
8: 1 \text {. the powders were milled for } 3 \mathrm{~h} \text {. } \\
\text { powders were cold- compacted for about } \\
5 \mathrm{~min} \text { under a pressure of } 350 \mathrm{MPa} \text {. } \\
\text { - Then, sintered under argon protected } \\
\text { atmosphere at } 800{ }^{\circ} \mathrm{C} \text { for about } 2 \mathrm{~h} \text {. }\end{array}$ & $\begin{array}{l}\text { At an applied load of } 5 \mathrm{~N} \text {, the } \\
\text { coefficient of friction and wear loss } \\
\text { of } 2 \% \text { CNTs reinforced } \mathrm{Cu}-\mathrm{Sn} \\
\text { alloy nanocomposite decrease by } \\
72 \% \text { and } 68 \% \text {, respectively, }\end{array}$ \\
\hline [128] & MWCNTs & $\begin{array}{l}\text { Dia(A): } \\
15-35 \mathrm{~nm}, \\
\text { Length(A): } \\
10 \mu \mathrm{m} \\
\text { Dia(B): } \\
9.5 \mathrm{~nm} \text {, } \\
\text { Length(B): } \\
1.5 \mu \mathrm{m}\end{array}$ & $\begin{array}{l}\text { Aluminium } \\
60 \mu \mathrm{m}\end{array}$ & $\begin{array}{l}\text { - Ultrasonication } \\
\text { process } \\
\text { - Compaction Process } \\
\text { - Sintering process }\end{array}$ & $\begin{array}{l}\text { - Using ultrasonication to disperse and } \\
\text { mix CNTs and Al powders. } \\
\text { - Then compacted. } \\
\text { - Then, the green samples sintered } \\
640^{\circ} \mathrm{C} \text { for } 90 \mathrm{~min} \text {. }\end{array}$ & $\begin{array}{l}\text { Improve the dispersion and promote } \\
\text { the production of nanocomposites } \\
\text { with better mechanical properties. } \\
\text { Vickers microhardness tests using a } \\
98 \mathrm{mN} \text { load }\end{array}$ \\
\hline [129] & MWCNTs & $\begin{array}{l}\text { Dia: } \\
3-5 \mathrm{~nm} \\
\text { Length: } \\
8-15 \mu \mathrm{m}\end{array}$ & Mg AZ61 & $\begin{array}{l}\text { - Water atomization } \\
\text { - Ultrasonication } \\
\text { - Ball Milling } \\
\text { - Microwave sintering }\end{array}$ & $\begin{array}{l}\text { - Atomized Mg AZ61 alloy to produce a } \\
\text { powder }(150-300 \mu \mathrm{m}) \text {. } \\
\text { - Reduce the particle size of AZ61 to } \\
50 \mu \mathrm{m} \text { by Mechanical Milling. } \\
\text { - Then, applied ultrasonication for } 20 \text { min } \\
\text { for the complete dispersion of CNTs in } \\
\text { the solution. And use microwave } \\
\text { sintering. }\end{array}$ & $\begin{array}{l}\text { Significant improvement in both } \\
\text { compressive and energy absorption } \\
\text { properties have been observed in } \\
\text { CNT-re- inforced Mg composite } \\
\text { foams. For samples with } 3 \% \text { CNTs } \\
\text { fraction and } 49 \% \text { porosity level, } \\
\text { improvements in compressive } \\
\text { strength and energy absorption are } \\
93 \% \text { and } 153 \% \text {, respectively. }\end{array}$ \\
\hline [130] & MWCNTs & $\begin{array}{l}\text { Dia: } \\
16 \mathrm{~nm} \\
\text { Length: } \\
900 \mathrm{~nm}\end{array}$ & $\begin{array}{l}\text { The coarse- } \\
\text { grained AA } \\
\text { and nano- } \\
\text { crystalline are } \\
\text { structured of } \\
\text { powders AA } \\
4032 \text {. }\end{array}$ & $\begin{array}{l}\text { - Energy ball milling } \\
\text { - Electric arc } \\
\text { discharge. } \\
\text { - Compacted process. } \\
\text { - Sintering process. }\end{array}$ & $\begin{array}{l}\text { - The powder prepared by ball milled for } \\
30 \mathrm{hr} \text { then MWCNTs added into ball } \\
\text { milling for } 15 \mathrm{~min} \text { to avoid the damage } \\
\text { of CNTs. } \\
\text { - Then, compacted under a uniaxial load } \\
\text { of } 650 \mathrm{MPa} \text { for } 2 \mathrm{~min} \text {. } \\
\text { - Finally, they were sintered under an } \\
\text { argon atmosphere at } 520 \mathrm{oC} \text { for } 90 \mathrm{~min}\end{array}$ & $\begin{array}{l}\text { The yield strength of the AA4032 } \\
\text { was double when the CNT was } \\
\text { added by } 2 \mathrm{wt} \% \text { its' jump from } \\
300 \mathrm{MPa} \text { to } 600 \mathrm{MPa}\end{array}$ \\
\hline [131] & CNTs & & $\begin{array}{l}\mathrm{Fe}-50 \mathrm{Co}-0.2 \mathrm{Si} \\
\text { alloy } \\
\text { powder( } 23.4 \\
\mu \mathrm{m})\end{array}$ & $\begin{array}{l}\text { - Gas atomization } \\
\text { - High energy ball- } \\
\text { milling. } \\
\text { - Spark plasma } \\
\text { sintering (SPS) }\end{array}$ & $\begin{array}{l}\text { - The powder was produced by gas } \\
\text { atomization, } \\
\text { - Then, entered the high energy ball } \\
\text { milling to achieve the uniform dispersion } \\
\text { at } 6 \text { th hour. } \\
\text { - Finally, the specimens goes into A spark } \\
\text { plasma sintering SPS furnace } 22 \text { mins.at } \\
50 \mathrm{MPa} \text { and vacuum atmosphere. }\end{array}$ & $\begin{array}{l}\text { As the ball-milling time increased, } \\
\text { the yield strength increased in the } \\
\text { composites; a maximum } 50 \% \\
\text { relative increase in tensile strength } \\
\text { due to the addition of CNTs was } \\
\text { achieved after } 1 \mathrm{~h} \text { ball-milling, } \\
\text { which then decreased with further } \\
\text { ball-milling. }\end{array}$ \\
\hline [112] & MWCNTs & $\begin{array}{l}\text { Dia: } \\
\text { 5-30 nm } \\
\text { Length: } \\
1-10 \mu \mathrm{m}\end{array}$ & $\begin{array}{l}\text { AZ91D alloy } \\
(75 \mu \mathrm{m})\end{array}$ & $\begin{array}{l}\text { - Ball milling with } \\
\text { stirring casting }\end{array}$ & $\begin{array}{l}\text { - CNTs were previously dispersed in } \\
\text { AZ91 alloy powder by ball milling } \\
\text { - Then, applied compact under a hydraulic } \\
\text { pressure of } 100 \mathrm{kN} \text {. } \\
\text { - Then, the alloy was melted at } 993 \mathrm{~K} \text { and } \\
\text { preheated CNTs block ( } 393 \mathrm{~K}) \text {. } \\
\text { - Then, CNTs added into alloy melt } \\
1073 \mathrm{~K} \text { then cooled down to } 933 \mathrm{~K} \text { and } \\
\text { stirred for } 3 \mathrm{~min} \text { with } 100 \mathrm{r} / \mathrm{min} \text {. }\end{array}$ & $\begin{array}{l}\text { Homogeneously distributed in the } \\
\text { matrix and maintained the } \\
\text { integrated structure. The yield } \\
\text { strength and ductility of } \\
\text { AZ91D/CNTs composite were } \\
\text { improved by } 47.2 \% \text { and } 112.2 \% \text {, }\end{array}$ \\
\hline [132] & MWCNTs & $\begin{array}{l}\text { (Dia: } \\
40 \mathrm{~nm} \\
\text { Length: } \\
2 \mu \mathrm{m}\end{array}$ & $\begin{array}{l}\text { AZ91D alloy } \\
(75 \mu \mathrm{m})\end{array}$ & $\begin{array}{l}\text { - Powder metallurgy } \\
\text { method. } \\
\text { - Mechanical agitator } \\
\text { - Vacuum drier } \\
\text { - Compact process } \\
\text { - Sintering process }\end{array}$ & $\begin{array}{l}\text { - CNTs were dispersed in ethanol using an } \\
\text { ultra-sonication process for } 1 \mathrm{~h} \text {. } \\
\text { - And the powder was dissolved in ethanol } \\
\text { to make a slurry } \\
\text { - Then CNTs dispersion was added } \\
\text { dropwise into powder slurry by using } \\
\text { mechanical agitator at } 1500 \mathrm{rpm} \text { for } 1 \mathrm{~h} \\
\text { then the slurry was put in vacuum dried } \\
\text { at } 651 \mathrm{C} \text { for } 10 \mathrm{~h} \\
\text { - After that, the powder mixture was }\end{array}$ & $\begin{array}{l}\text { The composite exhibited an } \\
\text { impressive increase in } \\
\text { microhardness (about p23\%) and } \\
\text { tensile failure strain value (about } \\
\text { p98\%) without significant } \\
\text { compromise in tensile strength, } \\
\text { compared to the un-reinforced Mg- } \\
3 \mathrm{Al}-1 \mathrm{Zn} \text { alloy. The synthesized } \\
\text { composites can be used }\end{array}$ \\
\hline
\end{tabular}

Continued on next page.

\section{Conclusion}

Despite all the previous encouraging dispersion and inspection techniques that were presented, challenges exist with regards to uniformly dispersing the CNTs within the metal matrix. This dispersing problem is a result of the bundling of CNTs and the meagre compatibility properties between CNT's and metals. While some degree of success 
Continued.

\begin{tabular}{|c|c|c|c|c|c|c|}
\hline & & & & & $\begin{array}{l}\text { compact with the pressure of } 550 \mathrm{MPa} \\
\text { finally the sintering process takes } 2 \mathrm{~h} \text { at } \\
630^{\circ} \mathrm{C} \text {. }\end{array}$ & \\
\hline [133] & MWCNTs & $\begin{array}{l}\text { Dia: } \\
9.5 \mathrm{~nm} \\
\text { Length: } \\
1.5 \mu \mathrm{m}\end{array}$ & $\mathrm{Mg}$ chips/Al & $\begin{array}{l}\text { - Ball Milling } \\
\text { - Cold pressing } \\
\text { - Hot extrusion }\end{array}$ & $\begin{array}{l}\text { - } \mathrm{Mg} \text { chips ball-milled under an argon } \\
\text { atmosphere at } 300 \mathrm{rpm} \text { for } 3 \mathrm{~h} \text {. } \\
\text { - Al powders used as a good binder in the } \\
\text { recycling of } \mathrm{Mg} \text { chips containing CNTs } \\
\text { through a hot extrusion process }\end{array}$ & $\begin{array}{l}\text { - The microstructure, mechanical } \\
\text { properties and corrosion behavior } \\
\text { of } \mathrm{Mg} / \mathrm{Al} \text { without CNT (base } \\
\text { alloy) and composites were } \\
\text { evaluated. } \\
\text { - A small addition of CNTs }(0.5 \\
\text { wt. \%) to the base alloy improved } \\
\text { the hardness and corrosion } \\
\text { resistance. }\end{array}$ \\
\hline [113] & MWCNTs & $\begin{array}{l}\text { Dia: } \\
\text { 20-40 nm } \\
\text { Length: } \\
1-5 \mu \mathrm{m}\end{array}$ & Mg AZ91D & $\begin{array}{l}\text { - Mechanical stirring } \\
\text { - Ultrasonic dispersion } \\
\text { processing }\end{array}$ & $\begin{array}{l}\text { - The melting was carried out using a } \\
\text { resistance heating furnace. } \\
\text { - The mechanical stirring was applied } \\
\text { - And CNTs were added into the stirring } \\
\text { vortex with speed } 300-500 \mathrm{rpm} \text { in } 2 \mathrm{~min} \\
\text { to ensure complete dispersion a high- } \\
\text { intensity ultrasonic wave with a } 20 \mathrm{kHz} \text {, } \\
\text { a maximum } 1.4 \mathrm{~kW} \text { power for } 15 \mathrm{~min} \text {, } \\
\text { - Then, the melted mixture was heated to } \\
700 \mathrm{C} \text { then cooled down. }\end{array}$ & $\begin{array}{l}\text { The microstructures and mechanical } \\
\text { properties of the nanocomposite } \\
\text { were investigated. the tensile } \\
\text { strength, yield strength, and } \\
\text { elongation } y \text { of the } \\
1.5 \% \text { CNTs/AZ91D nanocomposite } \\
\text { are improved by } 22 \%, 21 \% \text {, and } \\
42 \% \text { respectively. }\end{array}$ \\
\hline [134] & MWCNTs & $\begin{array}{l}\text { (Dia: } \\
50 \mathrm{~nm} \\
\text { Length: } \\
1-5 \mu \mathrm{m}\end{array}$ & $\begin{array}{l}\text { Al-Si alloys } \\
325 \pm 15 \mu \mathrm{m}\end{array}$ & $\begin{array}{l}\text { - Ball Milling } \\
\text { - Shot-blasting process } \\
\text { - Cold spray process }\end{array}$ & $\begin{array}{l}\text { - Mixing MWCNTs in aqueous dispersion } \\
\text { medium then alumina powders were } \\
\text { mixed with CNTs } \\
\text { - And dry-milled using a planetary ball } \\
\text { mill. } \\
\text { - Pretreated using a shot-blasting process. } \\
\text { - Then cold sprayed by a bond coat. } \\
\text { mixtures were } \\
\text { - Then, coated by a cold spraying process }\end{array}$ & $\begin{array}{l}\text { The optimum properties in the } \\
\text { hardness and wear resistance were } \\
\text { observed }\end{array}$ \\
\hline [135] & $\begin{array}{l}\mathrm{MWCNT}_{\mathrm{G}} \\
\mathrm{r}\end{array}$ & $\begin{array}{l}\text { Dia: } \\
\text { 20-30 nm } \\
\text { Length: } \\
10-30 \mu \mathrm{m}\end{array}$ & $\begin{array}{l}\text { Ti64 } \\
25 \mu \mathrm{m}\end{array}$ & 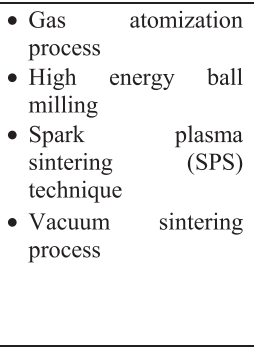 & $\begin{array}{l}\text { - High energy ball mill (HEBM), was } \\
\text { adapted for the mixing and dispersion of } \\
\text { MWCNT }_{\mathrm{Gr}} \text { in the Ti64 metal matrix for } \\
6 \mathrm{~h} \text { and } 50 \mathrm{rpm} \text {. } \\
\text { - Composite powder mixtures were } \\
\text { sintered in vacuum at constantly applied } \\
\text { pressure, heating rate and isothermal } \\
\text { holding time of } 50 \mathrm{MPa}, 100^{\circ} \mathrm{C} / \mathrm{min} \text { and } \\
5 \text { min. }\end{array}$ & $\begin{array}{l}\text { - The relative density of the } \\
\text { sintered MWCNTGr/Ti64 } \\
\text { composites was enhanced with } \\
\text { increased sintering temperature } \\
\text { but deteriorated with increased } \\
\text { wt } \% \text { MWCNTGr in the metal } \\
\text { matrix. } \\
\text { - Vickers microhardness } \\
\text { composites improved with } \\
\text { increasing sintering temperature } \\
\text { and weight fractions of } \\
\text { MWCNT }_{\text {Gr. }}\end{array}$ \\
\hline [136] & MWCNT & $\begin{array}{l}\text { Dia: } \\
20 \mathrm{~nm} \\
\text { Length: } \\
10-30 \mu \mathrm{m}\end{array}$ & $\begin{array}{l}\text { Copper } \\
300 \text { mesh }\end{array}$ & $\begin{array}{l}\text { - Ultrasonication } \\
\text { - High energy milling } \\
\text { - Spark plasma } \\
\text { sintering. } \\
\text { - Annealing treatment }\end{array}$ & $\begin{array}{l}\text { - Powders fabricated by ultrasonication } \\
\text { and mechanical milling with a rotation } \\
\text { speed of } 300 \mathrm{rpm} \text { for milling time of } 9 \text { to } \\
\text { achieve homogeneously mixture. } \\
\text { - Then, Spark plasma sintering applied on } \\
\text { composited with } 40 \mathrm{MPa} \text { uniaxial } \\
\text { vacuum, } 800 \mathrm{C} \text { and heating rate of } \\
100 \mathrm{C} / \mathrm{min} \text {. } \\
\text { - Then, it cooled down and annealed for } 1 \\
\text { h at } 800^{\circ} \mathrm{C} \text {. }\end{array}$ & $\begin{array}{l}\text { - The hardness and mechanical } \\
\text { properties of the composites were } \\
\text { improved by the addition of } \\
\text { CNTs. } \\
\text { - Hardness and tensile tests } \\
\text { demonstrated that the } \\
\text { homogeneous dispersion of CNTs } \\
\text { and high densification are the } \\
\text { critical problems that have to be } \\
\text { solved to enhance the mechanical } \\
\text { properties of } \mathrm{Cu} \text {-CNTs } \\
\text { nanocomposites. }\end{array}$ \\
\hline [137] & MWCNT & $\begin{array}{l}\text { Dia: } \\
20 \mathrm{~nm} \\
\text { Length: } \\
1-3 \mu \mathrm{m}\end{array}$ & $\begin{array}{l}6061 \mathrm{Al} \\
\text { powder } \\
(30 \mu \mathrm{m})\end{array}$ & $\begin{array}{l}\text { - Ball Milling } \\
\text { - High energy ball } \\
\text { milling } \\
\text { - Sintering process } \\
\text { - Hot extrusion process } \\
\text { - Hot rolling process }\end{array}$ & $\begin{array}{l}\text { - The 6061Al powder and MWCNTs } \\
\text { mixed were balls milled by integration of } \\
\text { low energy ball milling ( } 135 \mathrm{rpm} \text { for } 8 \mathrm{~h} \text { ). } \\
\text { - And high energy ball milling ( } 270 \mathrm{rpm} \\
\text { for } 1 \mathrm{~h}) \\
\text { - Then, sintered at } 550^{\circ} \mathrm{C} \text { for } 2 \mathrm{~h} \text { and hot } \\
\text { extruded into a plate after that the plate } \\
\text { was hot rolled into the thinner plate. }\end{array}$ & $\begin{array}{l}\text { The average grain size was reduced } \\
\text { from } 580 \mathrm{~nm} \text { to } 300 \mathrm{~nm} \text { with better } \\
\text { homogeneity after cold rolling, and } \\
\text { elongation to failure at } 400{ }^{\circ} \mathrm{C} \text { and } \\
4.17 \mathrm{E}-1 \mathrm{~s}-1 \text { was improved by } 40 \%\end{array}$ \\
\hline [138] & MWCNT & $\begin{array}{l}\text { Dia: } \\
\text { 15-30 nm } \\
\text { Length: } \\
1-5 \mu \mathrm{m}\end{array}$ & $\begin{array}{l}\text { Al powders } \\
(30 \mu \mathrm{m})\end{array}$ & $\begin{array}{l}\text { - Gas atomization } \\
\text { - Ball milling process } \\
\text { - Cold press process } \\
\text { - Sintering process } \\
\text { - Hot extruded process }\end{array}$ & $\begin{array}{l}\text { - Atomized spherical } \mathrm{Al} \text { powders. The } \mathrm{Al} \\
\text { powders and stearic acid (as agent) } \\
\text { mixed in a 3D mixer for } 1 \mathrm{~h} \text {. } \\
\text { - Then, the CNT/Al mixed in different ball } \\
\text { milling conditions. } \\
\text { - Then, cold pressed into u } 40 \mathrm{~mm} \text { columns } \\
\text { at } 500 \mathrm{MPa} \text {, sintered at } 550^{\circ} \mathrm{C} \text { for } 2 \mathrm{~h} \\
\text { and hot extruded. }\end{array}$ & $\begin{array}{l}\text { CNTs, SSBM CNT/Al composites } \\
\text { doubled or tripled the ductility of } \\
\text { Low-Speed Ball Milling (LSBM) } \\
\text { and High-Speed Ball Milling } \\
\text { (HSBM) CNT/Al, while their } \\
\text { strength was nearly similar. }\end{array}$ \\
\hline [139] & CNT & & $\mathrm{Al}$ & $\begin{array}{l}\text { - Ball milling process } \\
\text { - Compact process } \\
\text { - Sintering process } \\
\text { - Hot extrusion }\end{array}$ & $\begin{array}{l}\text { - The powders with different CNT content } \\
\text { were a mill for } 90 \text { min with a velocity of } \\
500 \mathrm{rpm} \text { in planetary ball mill filled with } \\
\text { Ar. Compacted under } 600 \mathrm{MPa} \text {. } \\
\text { - Then, sintered for } 1 \mathrm{~h} \text { at } 630^{\circ} \mathrm{C} \text {. }\end{array}$ & $\begin{array}{l}\text { - The } 4.5 \mathrm{wt} \% \text {-CNT/Al composites } \\
\text { exhibit the largest hardness and } \\
\text { tensile strength, which is } 2.3 \text { and } \\
2.4 \text { times higher than that of } \\
\text { starting Al. }\end{array}$ \\
\hline
\end{tabular}

Continued on next page.

has been reported in each of these methods, there are, however, still many issues that are being investigated (such as alignment of the CNTs, damaging of the CNTs etc.) and research continues in these areas.

\section{REFERENCES}

1) J.N. Coleman, U. Khan, W.J. Blau and Y.K. Gun'ko: Carbon 44 (2006) 1624-1652. 
Continued.

\begin{tabular}{|c|c|c|c|c|c|c|}
\hline & & & & & $\begin{array}{l}\text { - Finally, hot extrusion was conducted at } \\
500^{\circ} \mathrm{C} \text {. }\end{array}$ & $\begin{array}{l}\text { - The coefficient of thermal } \\
\text { expansions (CTEs) of the } \\
\text { composites decreased with the } \\
\text { increase of CNT content at the } \\
\text { temperature range of } 100-300{ }^{\circ} \mathrm{C} \text {. }\end{array}$ \\
\hline [140] & MWCNT & $\begin{array}{l}\text { Dia: } \\
15-30 \mathrm{~nm} \\
\text { Length: } \\
1-5 \mu \mathrm{m}\end{array}$ & $\begin{array}{l}\text { Copper } \\
35 \mu \mathrm{m}\end{array}$ & $\begin{array}{l}\text { - The high-energy ball } \\
\text { milling process } \\
\text { - Flake powder } \\
\text { metallurgy } \\
\text { - Hot-pressing process } \\
\text { - Hot-rolling process }\end{array}$ & $\begin{array}{l}\text { copper flaky powder }(60 \mathrm{~g}) \text { was } \\
\text { thoroughly mixed with dodecyl trimethyl } \\
\text { ammonium bromide }(20 \mathrm{mg}) \text { at room } \\
\text { temperature in } 800 \mathrm{~mL} \text { deionized water in } \\
0.5 \mathrm{~h} \text {. after filtration and drying they re- } \\
\text { dispersed in deionized water to produce } \\
\text { slurry then MWCNTs aqueous suspension } \\
\text { was added into the slurry slowly finally } \\
\text { The MWCNTs } / \mathrm{Cu} \text { flaky powder was } \\
\text { dried. } \\
\text { then compacted in hot-pressing applied at } \\
950^{\circ} \mathrm{C} \text { under } 50 \mathrm{MPa} \text { then hot-rolling } \\
\text { process at } 800^{\circ} \mathrm{C} \text {. }\end{array}$ & $\begin{array}{l}\text { The ultimate tensile strength of } 1.0 \\
\text { vol } \% \mathrm{MWCNTs} / \mathrm{Cu} \text { composite } \\
\text { reaches } 395 \mathrm{MPa} \text {, with an electric } \\
\text { conductivity of } 90 \% \text { IACS and an } \\
\text { elongation rate of more than } 20 \% \text {. }\end{array}$ \\
\hline [114] & MWCNT & $\begin{array}{l}\text { Dia: } \\
9.5 \mathrm{~nm} \\
\text { Length: } \\
1.5 \mu \mathrm{m}\end{array}$ & AA 7075 & - -Stir casting method & $\begin{array}{l}\text { - Al } 7075 \text { alloy were melted in the furnace } \\
\text { at } 850 \mathrm{oC} \text { then (MWCNT) powder was } \\
\text { preheated to a temperature of } 200 \mathrm{oC} \text { and } \\
\text { added to the molten metal Ar atmosphere } \\
\text { then the mixture was stir for } 15 \mathrm{~min} \text { at } \\
300 \mathrm{rpm}\end{array}$ & $\begin{array}{l}\text { The wear loss tends to decrease with } \\
\text { an increasing weight percentage of } \\
\text { reinforcement, which confirms that } \\
\text { the addition of MWCNT into the } \\
\text { base Aluminium matrix aids in } \\
\text { reducing the loss due to wear of the } \\
\text { composite. }\end{array}$ \\
\hline [141] & MWCNT & $\begin{array}{l}\text { Dia: } \\
1-1.2 \mathrm{~nm} \\
\text { Length: } \\
5-20 \mu \mathrm{m}\end{array}$ & $\mathrm{Cu}$ & $\begin{array}{l}\text { - Gas Atomization } \\
\text { process. } \\
\text { - Pre-bending process. } \\
\text { - Compact process. } \\
\text { - Sintering Process. }\end{array}$ & $\begin{array}{l}\mathrm{Cu} \text { and CNTs blended in a shear type } \\
\text { mixer for } 60 \text { mins then the mixture } \\
\text { compacted at room temperature with } \\
\text { pressure } 80 \mathrm{kN} \text { after that the sintering takes } \\
\text { place of temperature } 900{ }^{\circ} \mathrm{C} \text { for } 90 \text { mins in } \\
\text { an argon atmosphere. }\end{array}$ & $\begin{array}{l}\text { - The green density of copper } \\
\text { compact and composite compacts } \\
\text { was } 8.71 \text { and } 8.63 \mathrm{~g} / \mathrm{cm} 3 \text { for } 1 \% \\
\text { and } 2 \% \text { carbon nanotubes. } \\
\text { - The sintered density of the copper } \\
\text { and composites was also } \\
\text { measured and found to be } 8.76 \\
\text { and } 8.67 \mathrm{~g} / \mathrm{cm} 3 \text { for } 1 \% \text { and } 2 \% \\
\text { carbon nanotubes. }\end{array}$ \\
\hline [142] & MWCNTs & $\begin{array}{l}\text { Dia: } \\
60-100 \mathrm{~nm} \\
\text { Length: } \\
5-15 \mu \mathrm{m}\end{array}$ & $\begin{array}{l}\text { Al powder } \\
5 \mu \mathrm{m}\end{array}$ & $\begin{array}{l}\text { - High energy ball } \\
\text { milling. } \\
\text { - Low energy ball } \\
\text { millings. } \\
\text { - Polyester binder- } \\
\text { assisting. } \\
\text { - Spark plasma } \\
\text { sintering process. } \\
\text { - Hot extrusion } \\
\text { process. }\end{array}$ & $\begin{array}{l}\text {-Al- } 0.5 \text { wt.\% CNT powders were mixed by } \\
\text { stirring then the mixture was added into } \\
\text { high energy ball milling at } 200 \mathrm{rpm} \text { for } 4 \mathrm{~h} \text {. } \\
\text {-Al-CNTs powders and balls as used in } \\
\text { high energy ball milling but in a plastic } \\
\text { container then blended by horizontal roller } \\
\text { machine. } \\
\text {-polyethylene glycol (PEG) in a form of a } \\
\text { flake was hand mixed with CNTs. The } \\
\text { mixture was transferred into a Haake twin- } \\
\text { screw mixer. After that, all the mixture } \\
\text { obtained by spark plasma sintering follows } \\
\text { by hot extrusion. }\end{array}$ & $\begin{array}{l}\text { - The results of mechanical } \\
\text { properties revealed that the } \\
\text { powder mixing was successful. } \\
\text { - A small addition of CNTs }(0.5 \\
\text { wt.\%) could evidently enhance the } \\
\text { strength and hardness of the } \\
\text { composite compared with the pure } \\
\text { matrix. } \\
\text { - The TS and HV was PBA }(165,48) \\
\text { LEBM }(174,50) \\
\text { HEBM }(206,58) \text { Respectively }\end{array}$ \\
\hline [143] & MWCNTs & $\begin{array}{l}\text { Dia: } \\
\text { 20-50nm, } \\
\text { length: } \\
0.5-1.0 \mu \mathrm{m}\end{array}$ & $\begin{array}{l}\mathrm{Cu}-0.5 \mathrm{Ti} \\
(150 \mu \mathrm{m})\end{array}$ & $\begin{array}{l}\text { - Water atomization } \\
\text { - Powder Metallurgy } \\
\text { Process } \\
\text { - Spark plasma } \\
\text { sintering process }\end{array}$ & $\begin{array}{l}\text { composites were prepared by dipping raw } \\
\mathrm{Cu}-0.5 \mathrm{Ti} \text { powder into the zwitterionic } \\
\text { surfactant water solution with CNTs. Cu- } \\
0.5 \mathrm{Ti} / \mathrm{CNTs} \text { composite powders were } \\
\text { sintered by } \\
\text { using spark plasma sintering at } 950^{\circ} \mathrm{C} \text { for } \\
30 \text { mins under } 30 \mathrm{MPa} \text { pressure in a } \\
\text { vacuum atmosphere. Then the compacts } \\
\text { samples were preheated to } 800{ }^{\circ} \mathrm{C} \text { in } \mathrm{Ar} \\
\text { gas then immediately extruded. }\end{array}$ & $\begin{array}{l}\text { - } \mathrm{Cu}-0.5 \mathrm{Ti} / 0.19 \text { mass } \% \text { CNTs } \\
\text { composite alloy had 175.8MPa } \\
\text { YS. It was about } 2 \text { times as YS of } \\
\text { pure copper. } \\
\text { - The electrical conductivity of } \mathrm{Cu}- \\
0.5 \mathrm{Ti} / 0.19 \text { mass } \% \text { CNTs } \\
\text { composite alloy was } 83.5 \mathrm{IACS} \% \text {. } \\
\text { - The electrical conductivities of } \\
\mathrm{Cu}-0.5 \mathrm{Ti} / \mathrm{CNTs} \text { composite alloys } \\
\text { were increased compared to the } \\
\text { monolithic } \mathrm{Cu}-0.5 \mathrm{Ti} \text { alloy. }\end{array}$ \\
\hline
\end{tabular}

2) P.M. Ajayan: Chem. Rev. 99 (1999) 1787-1800.

3) J.N. Coleman et al.: Carbon 45(2) (2004) 167-173.

4) M. Moniruzzaman and K.I. Winey: Macromolecules 39 (2006) 5194 5205.

5) M. Cadek, J.N. Coleman, K.P. Ryan, V. Nicolosi, G. Bister, A. Fonseca, J.B. Nagy, K. Szostak, F. Béguin and W.J. Blau: Nano Lett. 4 (2004) 353-356.

6) M.-K. Yeh, N.-H. Tai and J.-H. Liu: Carbon 44 (2006) 1-9.

7) A. Peigney, C. Laurent, E. Flahaut and A. Rousset: Ceram. Int. 26 (2000) 677-683.

8) A. Peigney, E. Flahaut, C. Laurent, F. Chastel and A. Rousset: Chem. Phys. Lett. 352 (2002) 20-25.

9) Z. Xia, L. Riester, W.A. Curtin, H. Li, B.W. Sheldon, J. Liang, B. Chang and J.M. Xu: Acta Mater. 52 (2004) 931-944.

10) C.L. Xu, B.Q. Wei, R.Z. Ma, J. Liang, X.K. Ma and D.H. Wu: Carbon 37 (1999) 855-858.

11) T. Noguchi, A. Magario, S. Fukazawa, S. Shimizu, J. Beppu and M. Seki: Mater. Trans. 45 (2004) 602-604.

12) Q. Liu, L. Ke, F. Liu, C. Huang and L. Xing: Mater. Des. 45 (2013)
343-348

13) A. Esawi and K. Morsi: Compos., Part A 38 (2007) 646-650.

14) A.M.K. Esawi, K. Morsi, A. Sayed, A.A. Gawad and P. Borah: Mater Sci. Eng. A 508 (2009) 167-173.

15) S.R. Bakshi, D. Lahiri and A. Agarwal: Int. Mater. Rev. 55 (2010) 4164.

16) S.R. Bakshi and A. Agarwal: Carbon 49 (2011) 533-544.

17) S.R. Bakshi, A.K. Keshri and A. Agarwal: Mater. Sci. Eng. A 528 (2011) 3375-3384.

18) L. Jiang, Z. Li, G. Fan, L. Cao and D. Zhang: Scr. Mater. 66 (2012) 331-334.

19) N. Nouri, S. Ziaei-Rad, S. Adibi and F. Karimzadeh: Mater. Des. 34 (2012) 1-14.

20) H. Li, J. Kang, C. He, N. Zhao, C. Liang and B. Li: Mater. Sci. Eng. A 577 (2013) 120-124.

21) D.J. Woo, B. Sneed, F. Peerally, F.C. Heer, L.N. Brewer, J.P. Hooper and S. Osswald: Carbon 63 (2013) 404-415.

22) S.J. Yoo, S.H. Han and W.J. Kim: Scr. Mater. 68 (2013) 711-714.

23) N. Silvestre, B. Faria and J.N.C. Lopes: Compos. Sci. Technol. 90 
(2014) 16-24.

24) J. Stein, B. Lenczowski, E. Anglaret and N. Fréty: Carbon 77 (2014) 44-52.

25) A.M.K. Esawi, K. Morsi, A. Sayed, M. Taher and S. Lanka: Compos. Sci. Technol. 70 (2010) 2237-2241.

26) A.M.K. Esawi, K. Morsi, A. Sayed, M. Taher and S. Lanka: Compos., Part A 42 (2011) 234-243.

27) H.J. Choi, J.H. Shin and D.H. Bae: Compos. Sci. Technol. 71 (2011) 1699-1705.

28) H.J. Choi, J.H. Shin and D.H. Bae: Compos., Part A 43 (2012) 10611072

29) Z.Y. Liu, S.J. Xu, B.L. Xiao, P. Xue, W.G. Wang and Z.Y. Ma: Compos., Part A 43 (2012) 2161-2168.

30) S.E. Shin and D.H. Bae: Mater. Charact. 83 (2013) 170-177.

31) ASM Handbook: Properties and Selection: Nonferrous Alloys and Special-Purpose Materials, Vol. 2, (American Society for Metals, Materials Park, OH, 1990).

32) Y.-J. Kwon, M. Kobashi and N. Kanetake: Mater. Trans. 45 (2004) 3163-3171.

33) M. Wąsik and J. Karwan-Baczewska: Key Eng. Mater. 682 (2016) 270-275.

34) J. Stabik and A. Dybowska: Compos., Part B 127 (2017) 36-43.

35) X. He, G. Zou, Y. Xu, H. Zhu, H. Jiang, X. Jiang, W. Xia, J. Chen, J. Wu and S. Yang: Prog. Nat. Sci. Mater. Int. 28 (2018) 416-421.

36) G. Li, Y. Ma, X. He, W. Li and P. Li: Trans. Nonferrous Met. Soc. China 22 (2012) 1112-1117.

37) P.K. Saha: Aerospace Manufacturing Processes, (CRC Press, Boca Raton, 2016).

38) T. Dursun and C. Soutis: Mater. Des. 56 (2014) 862-871.

39) G.B.V. Kumar, C.S.P. Rao and N. Selvaraj: J. Miner. Mater. Charact. Eng. 10 (2011) 59-91.

40) M. Kathiresan and T. Sornakumar: Ind. Lubr. Tribol. 62 (2010) 361371.

41) S. Srivastava, S. Mohan, Y. Srivastava and A.J. Shukla: Int. J. Mod. Eng. Res. 2(2) (2012) 25-42.

42) H. Beygi, S.A. Sajjadi and S.M. Zebarjad: Mater. Sci. Eng. A 607 (2014) 81-88.

43) A.J. Knowles, X. Jiang, M. Galano and F. Audebert: J. Alloy. Compd. 615 (2014) S401-S405.

44) M. Yamaguchi, F. Meng, K. Firestein, K. Tsuchiya and D. Golberg: Mater. Sci. Eng. A 604 (2014) 9-17.

45) B. Liu, W. Huang, H. Wang, M. Wang and X. Li: J. Compos. Mater. 48 (2014) 355-364.

46) B. Huang, J.M. Zeng, Z.L. Hu, H. He, C.Y. He and J.L. Yan: Adv. Mater. Res. 900 (2014) 794-797.

47) P. Gudlur, A. Boczek, M. Radovic and A. Muliana: Mater. Sci. Eng. A 590 (2014) 352-359.

48) A. Ahmadi, M.R. Toroghinejad and A. Najafizadeh: Mater. Des. 53 (2014) 13-19.

49) M. Murali, M. Sambathkumar and M.S.S. Saravanan: Univers. J. Mater. Sci. 2 (2014) 49-53.

50) M. Nagaral, V. Bharath and V. Auradi: J. Mater. Sci. Eng. 2 (2013) $2-$ 5.

51) K. Edalati, M. Ashida, Z. Horita, T. Matsui and H. Kato: Wear 310 (2014) 83-89.

52) M. Rashad, F. Pan, J. Zhang and M. Asif: J. Alloy. Compd. 646 (2015) 223-232.

53) M. Rashad, F. Pan, M. Asif and A. Tang: J. Ind. Eng. Chem. 20 (2014) 4250-4255.

54) Q.C. Jiang, H.Y. Wang, B.-X. Ma, Y. Wang and F. Zhao: J. Alloy. Compd. 386 (2005) 177-181.

55) E.F. Emley: Principles of Magnesium Technology, (Pergamon Press, New York, London, 1966).

56) M. Rashad, F.S. Pan, M. Asif and A. Ullah: Mater. Sci. Technol. 31 (2015) 1452-1461.

57) T. Zhang, Z. Tao and J. Chen: Mater. Horiz. 1(2) (2014) 196-206.

58) H. Xiong, K. Yu, X. Yin, Y. Dai, Y. Yan and H. Zhu: J. Alloy. Compd. 708 (2017) 652-661.

59) J. An, R.G. Li, Y. Lu, C.M. Chen, Y. Xu, X. Chen and L.M. Wang: Wear 265 (2008) 97-104.

60) M. Rashad, F. Pan, A. Tang, M. Asif, J. She, J. Gou, J. Mao and H.
Hu: J. Compos. Mater. 49 (2015) 285-293.

61) J.C. Viala, P. Fortier, G. Claveyrolas, H. Vincent and J. Bouix: J. Mater. Sci. 26 (1991) 4977-4984.

62) Y. Kagawa and E. Nakata: J. Mater. Sci. Lett. 11 (1992) 176-178.

63) F. Wu, J. Zhu, Y. Chen and G. Zhang: Mater. Sci. Eng. A 277 (2000) 143-147.

64) M. Rashad, F. Pan, A. Tang, Y. Lu, M. Asif, S. Hussain, J. She, J. Gou and J. Mao: J. Magnes. Alloy. 1 (2013) 242-248.

65) A.D. Moghadam, E. Omrani, P.L. Menezes and P.K. Rohatgi: Compos., Part B 77 (2015) 402-420.

66) D. Segal: Materials for the 21st Century, (Oxford University Press, Oxford, 2017).

67) "UCLA researchers create exceptionally strong and lightweight new metal | UCLA.” [Online]. Available: http://newsroom.ucla.edu/ releases/ucla-researchers-create-exceptionally-strong-and-lightweightnew-metal. [Accessed: 01-Jan-2019].

68) E. Aghion and B. Bronfin: Mater. Sci. Forum 350-351 (2000) 19-30.

69) K.U. Kainer: Magnesium: Proceedings of the 7th International Conference on Magnesium Alloys and their Applications, (John Wiley \& Sons, Hoboken, 2007)

70) S. Fleming: Master Thesis, Eng. Mech. Eng. Fac. Rensselaer Polytech. Institute, Rensselaer Polytech. Inst. (2012).

71) E.F. Horst and B.L. Mordike: Magnesium Technology: Metallurgy, Design Data, Application, (Springer-Verlag, Berlin Heidelberg, 2006).

72) G. Cole: IMA-PROCEEDINGS-, (1995), pp. 1-5

73) S. LeBeau and R. Decker: Paper presented at the 5th Int. Conference on Semi-Solid Processing of Alloys and Composites, (Colorado School of Mines, Denver, Colorado, 1998) pp. 387-395.

74) T. Ito, M. Sato and Y. Kojima: Annual World IMA 2000 Magnesium Conference, (2000) pp. 33-40.

75) G.V. Raynor: The Physical Metallurgy of Magnesium and Its Alloys, (Pergamon Press2, London Google Sch., 1959).

76) C.S. Roberts: Magnesium and its Alloys, Vol. 180, (Wiley, Hoboken, New York, 1960).

77) D. Eliezer, E. Aghion and F.H.S. Froes: Adv. Perform. Mater. 5 (1998) 201-212.

78) E. Aghion, B. Bronfin, F. Von Buch, S. Schumann and H. Friedrich: JOM 55(11) (2003) 30-33.

79) M.K. Kulekci: Int. J. Adv. Manuf. Technol. 39 (2008) 851-865.

80) B. Gwynne and P. Lyon: "Magnesium alloys in aerospace applications, past concerns, current solutions," in Trienn. Int. Aircr. Fire Cabin Saf. Res. Conf., (2007).

81) W.A. Monteiroi, S.J. Busoi and L.V. da Silvai, Application of Magnesium Alloys in Transport, New Features on Magnesium Alloys, (InTech, 2012)

82) S.C. Erickson: SAE Trans. 86 (1977) 1418-1429.

83) E. Aghion, B. Bronfin and I. Schwartz: Israel Annual Conference on Aerospace Sciences, (1996) pp. 353-362.

84) K. Chu, C. Jia, W. Li and P. Wang: Phys. Status Solidi 210 (2013) 594-599.

85) H. Dai: Carbon Nanotubes: Synthesis, Structure, Properties, and Applications, Topics in Applied Physics, Vol. 80, (Springer, Berlin, 2001).

86) H. Yue, L. Yao, X. Gao, S. Zhang, E. Guo, H. Zhang, X. Lin and B. Wang: J. Alloy. Compd. 691 (2017) 755-762.

87) G.Q. Han, J.H. Shen, X.X. Ye, B. Chen, H. Imai, K. Kondoh and W.B. Du: Mater. Lett. 181 (2016) 300-304.

88) H. Zein: World J. Appl. Chem. 3 (2018) 17-27.

89) Y. Li, M. Li, M. Pang, S. Feng, J. Zhang and C. Zhang: J. Mater Chem. C 3 (2015) 5573-5579.

90) M.O. Mohsen, R. Taha, A. Abu Taqa, N. Al-Nuaimi, R.A. Al-Rub and K.A. Bani-Hani: J. Nanomater. 2017 (2017) 6927416.

91) S. Simões, F. Viana, M.A.L.L. Reis and M.F. Vieira: Microsc. Microanal. 22(no. S4) (2016) 52-53.

92) S. Simões, F. Viana, M.A.L. Reis and M.F. Vieira: Metals 7 (2017) 279.

93) Z.Y. Liu, B.L. Xiao, W.G. Wang and Z.Y. Ma: Compos., Part A 94 (2017) 189-198.

94) J.M. Tao, X.F. Chen, P. Hong and J.H. Yi: J. Alloy. Compd. 717 (2017) 232-239.

95) Q. Li, A. Viereckl, C.A. Rottmair and R.F. Singer: Compos. Sci. 
Technol. 69 (2009) 1193-1199.

96) J.L. Song, W.G. Chen, L.L. Dong, J.J. Wang and N. Deng: J. Alloy. Compd. 720 (2017) 54-62.

97) S.C. Tjong: Mater. Sci. Eng. Rep. 74 (2013) 281-350.

98) H. Fukuda, K. Kondoh, J. Umeda and B. Fugetsu: Compos. Sci. Technol. 71 (2011) 705-709.

99) G. Han, Z. Wang, K. Liu, S. Li, X. Du and W. Du: Mater. Sci. Eng. A 628 (2015) 350-357.

100) M. Paramsothy, X.H. Tan, J. Chan, R. Kwok and M. Gupta: Mater Des. 45 (2015) 15-23.

101) G.Q. Han, J.H. Shen, X.X. Ye, B. Chen, H. Imai, K. Kondoh and W.B. Du: Mater. Lett. 181 (2016) 300-304.

102) Q. Yuan, G. Zhou, L. Liao, Y. Liu and L. Luo: Carbon 127 (2018) 177-186.

103) H. Lyu, B. Gao, F. He, A.R. Zimmerman, C. Ding, H. Huang and J. Tang: Environ. Pollut. 233 (2018) 54-63.

104) M. Tokita: Spark Plasma Sintering (SPS) Method, Systems, and Applications, ed. by S. Somiya, 2nd ed., Chap. 11.2.3, S. B. T.-H. of A. C., (Academic Press, Oxford, 2013) pp. 1149-1177.

105) H.-C. Hsu, J.-Y. Chou and W.-H. Tuan: J. Asian Ceram. Soc. 4 (2016) 201-204.

106) Y. Huang, J. Li, L. Wan, X. Meng and Y. Xie: Mater. Sci. Eng. A 732 (2018) 205-211.

107) J. Liang, H. Li, L. Qi, W. Tian, X. Li, X. Chao and J. Wei: J. Alloy. Compd. 728 (2017) 282-288.

108) K. Kondoh, H. Fukuda, J. Umeda, H. Imai and B. Fugetsu: Carbon 72 (2014) 15-21.

109) Q.H. Yuan, X.S. Zeng, Y. Liu, L. Luo, J.B. Wu, Y.C. Wang and G.H Zhou: Carbon 96 (2016) 843-855.

110) S.E. Shin and D.H. Bae: Compos., Part B 134 (2018) 61-68.

111) P.S. Samuel Ratna Kumar, D.S. Robinson Smart and S. John Alexis: J. Asian Ceram. Soc. 5 (2017) 71-75.

112) Q. Yuan, D. Fu, X. Zeng and Y. Liu: Trans. Nonferrous Met. Soc. China 27 (2017) 1716-1724.

113) S.Y. Liu, F.P. Gao, Q.Y. Zhang, X. Zhu and W.Z. Li: Trans. Nonferrous Met. Soc. China 20 (2010) 1222-1227.

114) O. Aranke, C. Gandhi, N. Dixit and P. Kuppan: Mater. Today Proc. 5 (2018) 7748-7757.

115) Z. Yu, W. Yang, C. Zhou, N. Zhang, Z. Chao, H. Liu, Y. Cao, Y. Sun, P. Shao and G. Wu: Carbon 141 (2019) 25-39.

116) S. Sud and A. Kamath: Int. Res. J. Pharm. 4 (2013) 57-64.

117) B. Duan, Y. Zhou, D. Wang and Y. Zhao: J. Alloy. Compd. 771 (2019) 498-504.

$118)$ L. Liu, R. Bao, J. Yi, C. Li, J. Tao, Y. Liu, S. Tan and X. You: J. Alloy. Compd. 726 (2017) 81-87.

119) C. Parswajinan, B. Vijaya Ramnath, M. Vetrivel, A. Ranjith, B.K. Rohit, S. Vasanth and S. Vignesh: Mater. Today Proc. 5 (2018) 1176 1185 .

120) S. Simões, F. Viana, M.A.L. Reis and M.F. Vieira: Compos. Struct 108 (2014) 992-1000.

121) B. Vijaya Ramnath, C. Parswajinan, C. Elanchezhian, S. Venkatesan Pragadeesh, C. Kavin, P.R. Ramkishore and V. Sabarish: Appl. Mech. Mater. 680 (2014) 7-10.

122) B. Chen, S. Li, H. Imai, L. Jia, J. Umeda, M. Takahashi and K. Kondoh: Mater. Des. 72 (2015) 1-8

123) P.C. Tsai, Y.R. Jeng, J.T. Lee, I. Stachiv and P. Sittner: Diamond Related Materials 74 (2017) 197-204.

124) X. Chen, J. Tao, J. Yi, C. Li, R. Bao, Y. Liu, X. You and S. Tan: Mater Sci. Eng. A 712 (2018) 790-793.

125) K. Kondoh, H. Fukuda, J. Umeda, H. Imai, B. Fugetsu and M. Endo: Mater. Sci. Eng. A 527 (2010) 4103-4108.

126) Y. Ma, X. Yang, C. He, K. Yang, J. Xu, J. Sha, C. Shi, J. Li and N.
Zhao: Mater. Lett. 233 (2018) 351-354.

127) H.M. Mallikarjuna, K.T. Kashyap, P.G. Koppad, C.S. Ramesh and R. Keshavamurthy: Trans. Nonferrous Met. Soc. China 26 (2016) 17551764

128) S. Simoes, P.J. Ferreira, F. Viana, M.A.L. Reis and M.F. Vieira: Microsc. Microanal. 23(no. S1) (2017) 1942-1943.

129) A.D. Akinwekomi, W.-C. Law, M.-T. Choy, L. Chen, C.-Y. Tang, G.C.-P. Tsui and X.-S. Yang: Mater. Sci. Eng. A 726 (2018) 82-92.

130) T. Nagaraj, A. Abhilash, R. Ashik, M.S. Senthil Saravanan, S.P.K Babu and M. Rajkumar: Mater. Today Proc. 5 (2018) 6717-6721.

131) A.J. Albaaji, E.G. Castle, M.J. Reece, J.P. Hall and S.L. Evans: Mater Des. 122 (2017) 296-306.

132) M. Rashad, F. Pan, M. Asif and L. Li: Prog. Nat. Sci. Mater. Int. 25 (2015) 276-281.

133) H. Mindivan, A. Efe, A.H. Kosatepe and E.S. Kayali: Appl. Surf. Sci 318 (2014) 234-243.

134) W. Winarto, D. Priadi, N. Sofyan and A. Wicaksono: Procedia Eng. 170 (2017) 108-112.

135) A.O. Adegbenjo, P.A. Olubambi, J.H. Potgieter, M.B. Shongwe and M. Ramakokovhu: Mater. Des. 128 (2017) 119-129.

136) H. Deng, J. Yi, C. Xia and Y. Yi: J. Alloy. Compd. 727 (2017) 260268.

137) G. Fan, H. Huang, Z. Tan, D. Xiong, Q. Guo, M. Naito, Z. Li and D. Zhang: Mater. Sci. Eng. A 708 (2017) 537-543.

138) R. Xu, Z. Tan, D. Xiong, G. Fan, Q. Guo, J. Zhang, Y. Su, Z. Li and D. Zhang: Compos., Part A 96 (2017) 57-66.

139) X. Yang, T. Zou, C. Shi, E. Liu, C. He and N. Zhao: Mater. Sci. Eng. A 660 (2016) 11-18.

140) J. Liu, D.-B. Xiong, Z. Tan, G. Fan, Q. Guo, Y. Su, Z. Li and D. Zhang: Mater. Sci. Eng. A 729 (2018) 452-457.

141) G. Goudah, F. Ahmad and O. Mamat: J. Eng. Sci. Technol. 5 (2010) 272-283.

142) J. Liao and M.J. Tan: Powder Technol. 208 (2011) 42-48.

143) H. Imai, K. Kondoh, S. Li, J. Umeda, B. Fugetsu and M. Takahashi: Mater. Trans. 55 (2014) 522-527.

144) E.T. Thostenson and T.-W. Chou: J. Phys. D 36 (2003) 573.

145) S.R. Bakshi, J.E. Tercero and A. Agarwal: Compos., Part A 38 (2007) 2493-2499.

146) M. Kulkarni, D. Carnahan, K. Kulkarni, D. Qian and J.L. Abot: Compos., Part B 41 (2010) 414-421.

147) D.N. Savvas, V. Papadopoulos and M. Papadrakakis: Int. J. Solids Struct. 49 (2012) 3823-3837.

148) C.-H. Tsai, C.-J. Chang, K. Wang, C. Zhang, Z. Liang and B. Wang: IIE Trans. 44 (2012) 590-602.

149) M.A. Bhuiyan, R.V. Pucha, J. Worthy, M. Karevan and K. Kalaitzidou: Comput. Mater. Sci. 79 (2013) 368-376.

150) C. Lainé, P. Le Grognec, S. Panier and C. Binetruy: Eur. J. Mech. 47 (2014) 231-245.

151) C.D. Li, X.J. Wang, W.Q. Liu, K. Wu, H.L. Shi, C. Ding, X.S. Hu and M.Y. Zheng: Mater. Sci. Eng. A 597 (2014) 264-269.

152) A. Alizadeh, A. Abdollahi and H. Biukani: J. Alloy. Compd. 650 (2015) 783-793.

153) I. Duarte, E. Ventura, S. Olhero and J.M.F. Ferreira: Mater. Lett. 160 (2015) 162-166.

154) J. Ning, J. Zhang, Y. Pan and J. Guo: Mater. Sci. Eng. A 357 (2003) 392-396.

155) S. Ruan, P. Gao and T.X. Yu: Polymer 47 (2006) 1604-1611.

156) H. Rokni, A.S. Milani, R.J. Seethaler and K. Stoeffler: Compos. Struct. 94 (2012) 2538-2547.

157) J.G. Park, D.H. Keum and Y.H. Lee: Carbon 95 (2015) 690-698.

158) Y. Wang, S. Kim, G.P. Li and L.Z. Sun: Comput. Mater. Sci. 104 (2015) 69-75. 